
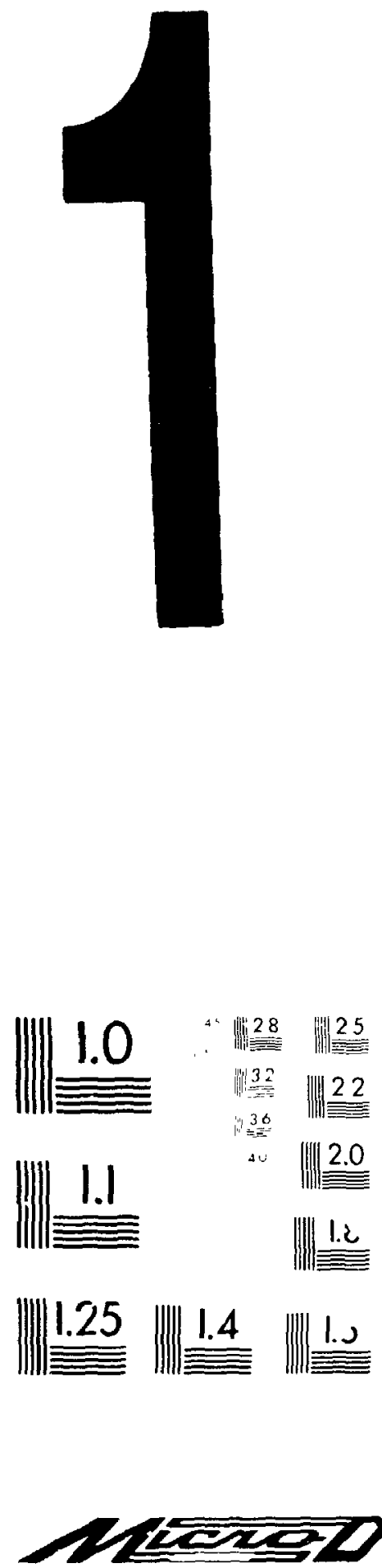
National Library

of Canada

\section{Canadian Theses Service}

Orawa. Canada

K1A ON 4
Bibliothèque nationale

du Canada

\section{Service des thèses canadiennes}

NOTICE

The quality of this microform is heavily dependent upon the quality of the original thesis submitted for microfilming. Every eftont has been made to ensure the highest quality of reproduction possible.

If pages are missing. contact the university which granted the degree.

Some pages may have indistinct print especially if the original pages were typed with a poor typewriter ribbon or if the university sent us an inferior pholocopy.

Reproduction in full or in part of this microform is governed by the Canadian Copyright ACt, R.S.C. 1970, C. C-30, and subsequent amendments

\section{AVIS}

La qualıe de celte microtorme dépend grandement de la qualté de la thèse soumise au microfilmage Nous avons tout fait pour assurer une qualité supérieure de reproduc tion

S'll má:aue des pages, veuillez communiquer avec l'université qui a conféré le grade

La qualıté d'ımpressıon de certaines pages peut laısser à désirer, suntout sı les pages origırales ont élé dactylogra. phiées à l'aide d'un ruban usé ou si l'universtté nous a falt parvenır une photocopie de qualité intérıeure

La reproduction, méme partielle, de cette microtorme est soumise a la Lo canadienne sur le droit d'auteur. SRC 1970, c C.30, et ses amendements subséquents 
DEVELOPMENT, DECAY, RE-DEVELOPMENT:

The Politics of the Northwest Territories

by

Lorraine Hewlett, E.A.

A thesis submitted to

the Faculty of Graduate Studies and Research

ir partial fulfilment of

the requirements for the degree of

Master of A.ts

Department of Political Science

\author{
Carleton University \\ Ottuwa, Ontario \\ 25 April 1989 \\ e copyright \\ 1989, Lorraine Hewlett
}


The author has granted an irrevocable nonexclusive licence allowing the National Library of Canada to reproduce, loan, distribute or sell copies of his/her thesis by any means and in any form or format, making this thesis available to interested persons.

The author retains ownership of the copyright in his/riai thesis. Neither the thesis nor substantial extracts from it may be printed or otherwise reproduced without his/her permission.
L'auteur a accordé une licence irrévocable et non exclusive permettant à la Bibliothèque nationale du Canada de reproduire, prêter, distribuer ou vendre des copies de sa thèse de quelque manière et sous quelque forme que ce soit pour mettre des exemplaires de cette thèse à la disposition des personnes intéressées.

L'auteur conserve la propriété du droit d'auteur qui protège sa thèse. Ni la thèse ni des extraits substantiels de celle-ci ne doivent être imprimés ou autrement reproduits sans son autorisation. 
The undersigned recommend to

the Faculty of Graduate Studies and Research acceptance of the thesis

"DEVELOPMENT, DECAY AND RE-DEVELOPMENT:

THE POLITICS OF THE NORTHWEST TERRITORIES"

submitted by Lorraine Hewlett, B.A.(Hon.)

in partial fulfilment of the requirements for

the degree of Master of Arts
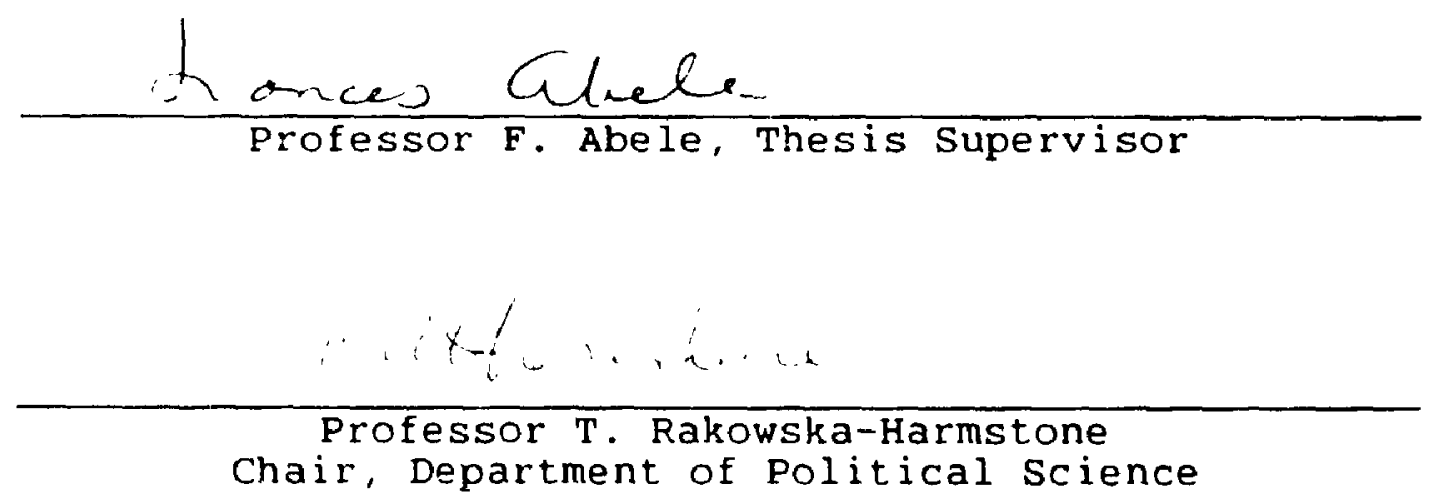

Chair, Department of Political science

Carleton University

May 12, 1989 


\section{Abstract}

There has been an inappropriate framework used for the analysis of political development in the Northwest Territories. This inappropriate framework assumes that political development is unilinear (or one-way) and is ultimately achieved when a territory finally adopts a Western, European, "modern" model of government. The argument in this thesis is that it is not true that the N.W.T. has been experiencing an ever-increasing level of political development since decolonization began and since more "responsible government" has been accorded. Rather, it is argued that first, before the introduction of the EuroCanadian model to the N.W.T., there existed political development in Native governments; secondly, in the twentieth century political decay was experienced in both Native and non-Native governments ; and thirdly, since 1975, a period of political re-development has been taking place in the N.W.T.. 
TABLE OF CONTENTS

CHAPTER

I. FRAMEWORK FOR ANALYSIS

A. Introduction..................

B. Debate in Canadian Politics........7

C. Debate in Comparative Politics...... 14

D. Political nevelopment and

Political Decay...............22

E. Summary...........................

F. Endnotes........................ 32

I . POLITICAL DE:ELOPMENT............33

A. Traditional Native Government......34

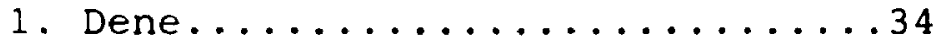

2. Inuit...............42

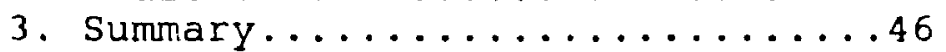

B. Euro-Canadian Government.........46

C. Endnotes.....................59

III. POLITICAL DECAY..............60

A. Serious Decay of Native Government

$(1922-1950 s) \ldots \ldots \ldots \ldots \ldots 2$

B. Summary.................... 74

C. Serious Decay of Euro-Canadian Government

(1950s-1975).................75

1. Superimposition of the Euro-Canadian Model.........76

2. Conflict over Economic

Priorities............... 89

D. Summary....................94 
IV. POLITICAL RE-DEVELOPMENT..........96

A. Conditions Contributing to

Political Development..........998

1. Federal Government Response....98

2. Increasing Organization and Solidarity of

Native Organizations.........103

3. Response of the

Territorial Government.......105

B. Important Criteria for Future

Political Development .............109

1. Cultural Protection and

Meaningful Partjcipation ......109

2. Cultural Equality ................117

3. Devolution of Power .........119

4. New Definition of

Economic Development........122

C. summary........................ 124

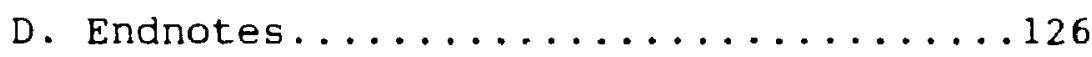

V. POLITICAL CULTURE AND POLITICAL DEVELOPMENT

A. Case Study: Party Politics........127

B. CONCLUSION..................... 440

BIBLIOGRAPHY ...................... 448 
Chapter One: Framework for Analysis

\section{NTRODUCT ION}

In the last decade, the idea that the Northwest Territories (N.W.T.) has been a culony within Canada has become increasingly accepted. The simllarities between conditions in the N.W.T. and in many underdeveloped countries, emerging from colonial status to full nationhood, have prompted Canadian scholars and laypeople alike to adopt, in their discussions about the political situation in the N.W.T., some of the vocabulary and concepts used in the international scene to describe a subject people arising from crionial status. In international development iiterature, the use of the term "political development" was first widely applied in the 1950 s when analysts were discussing what they considered to be "developing" countries in Africa, South America, and Asia. Since then, the term has been borrowed for discussions about the political situation in the N.W.T..

This thesis will focus on the canadian use of the term "political development" when analyzing the N.W.T.. My argument is that there has been an inappropriate framework used for the analysis of political development in the N.W.T.. This inappropriate framework assumes that political development is unilinear and is ultimately achieved with a territory's final adoption of a western, 
European, "modern" model of government. Furthermore, the framework allows for a state of increasing political development only when a decolonizing territory adopts a greater number of institutions belonging to the EuroCanadian model, the system of government in southern Canada. However, this thesis will argue that it is not true that the N.W.T. has been experiencing an everincreasing level of political development since decolonization began and since mure "responsible government" has been accorded, but that in the N.W.T., before the introduction of the Euro-Canadian model, there existed political development in Native gorernments; that in the twentieth century political decay was experienced $i_{11}$ both Native and non-Native governments; and that, since 1975, a period of political re-development has been taking place in the N.W.T..

The thesis will consist of five chapters. In the first chapter it will be seen that although there has been rigourous debate concerning the term "political development" in the field of comparative politics, similar dibate has not occurred in Canaca. Use of the term in the study of the N.W.T. has carried with it some of the same underlying assumptions and limiting valuejudgements as occurred, earlier, in the field of comparative politics. In chapter one a survey of Canadian scholarly literature will point out the 
existence of two schools of thought which present polar interpretations of the state of political development in the N.W.T. This will be followed, in the same chapter, by an examination of some aspects of the debate concerning political development that occurred in the field of comparative politics literature during the $1960 \mathrm{~s}$ and 1970s. The comparative literature sheds light on some unsuitable assumptions and value judgements that can arise when discussing the concept of "development". The third section of Chapter one will present a framework of political development and political decay that will be used in the proceeding chapters to more appropriately explain the events in the political history of the N.W.T. .

Chapter Two will argue that political culture plays a significant role in political development. This is true in the sense that the kinds of procedures and organizations that will become highly valued and heavily institutionalized in a political system are very much determined by the political culture of the people living within the system. In Chapter Two it will be seen how, before the signing of Treaties No. 8 and 11 , three different political systems were developing simultaneously in the N.W.T. according to the political culture of the Dene, Inuit, and Euro-canadians, respectively. The examination of the political systems of 
the Dene and Inuit, respectively, encompasses thousands of years. What will be described is what is believed to be general common features. For the description of the traditional Dene political system, there is a heavy reliance upon Leslie Malloch's compilation of the memories of Dene elders, given in a five day workshop in Edzo. The purpose of the workshop was "to describe the Dene model of 'consensus government' within the context of the traditional Dene way of life in which it evolved" [Malloch 1984:3]. Malloch's role was to serve as the recorder. It is realized that anthroplogists may question the validity of Malloch's work. However, the memories of Dene elders have been recognized to be quite good; in addition, the Native oral tradition is known to be a reliable source of information. Since the Inuit elders have not, up to the present time, compiled a comprehensive documentation of their traditional style of government, the information concerning Inuit government has been distilled from numerous anthropological sources. The sources of information for the Euro-Canadian section consist of a number of studies by Canadian historians and political scientists. For simplicity, there will be no discussion of the Inuvialuit, or of regional variations among the Dene and Inuit.

Chapter Three will argue that these three systems experienced political decay, at different times and for 
different reasons. The task of this chapter is to distill the major factors leading to the political decay of both the Native and non-native governments. Using Huntington's criteria for political decay which are applicable to the N.W.T., the political history of the N.W.T. has been examined for the factors which would appear to explain the obvious signs of political decay that occurred in the N.W.T.. This history is found in the Berger Inquiry, Malloch's compilation of Dene memories, numerous historical studies (by Natives and non-Natives) and anthropological studies.

Chapter Four will identify the current conditions of the political situation in the N.W.T. that are encouraging the political re-development of the N.W.T. and will bring to light several important criteria which must be met for the future political development of the N.W.T.. It will be seen how such things as the western Constitutional Forum and the Nunavut Constitutional Forum, the quest for division of the N.W.T., the effort to practise consensus government in the Northwest Territories Legislative Assembly (N.W.T.I.A.), the devolution of powers to the communities, and debate over the Denendeh Proposal (1981), the Nunavut Proposal (1976) and the Consociational model (1985) all play an essential part in the political re-development of the N.W.T.. Most sources of information, if not all, for this section have 
been published since 1975 and consist of scholarly studies, publications by both the territorial and federal governments, and the various proposals for political development put forward by Natives and non-Natives alike. The purpose of Chapter Five is to present a case study of a particular issue of political development in the N.W.T.: the style of decision-making in the Northwest Territories Legislative Assembly (N.W.T.L.A.). This chapter was inspired by my personal observation, during a two-week period, of the style of decision-making in the N.W.T.L.A. and by arguments put forth by Gad Horowitz, David Siegel, and James Gillies about the problems with democracy in a political system governed by a style of party politics. Chapter Five will refute the argument, made by some people, that party politics is necessary for political development in the N.W.T.. In this chapter, it will be seen that democracy is an essential aspect of Native political culture and that the style of decisionmaking which nas developed in the N.W.T.L.A., now labelled "consensus government", allows the closest approximation possible to democracy in Canada. Thus "consensus government" should be seen as an aspect of political development, in and of itself, based on the political culture of the territory. It will be argued that tlee imposition of party politics will not cause 
political development.

My conclusion, quite briefly, will be that the political history of the N.W.T. shows first, a long period of political development for the traditional Native governments and a relatively short period of political development for the early Euro-Canadian model; secondly, a period of serious political decay for the Native governments beginning early in the twentieth century and for the Euro-Canadian government beginning in the mid-twentieth century; and thirdly, that since 1975, a period of political re-development is taking place in which attempts are being made to integrate the different aspects o: the Native and non-Native political systems which continue to be heavily institutionalized.

\section{Debate in Canadian Literature}

The term political development continues to be used ambiguousiy, but for all the variation, something of a consensus is beginning to emerge.

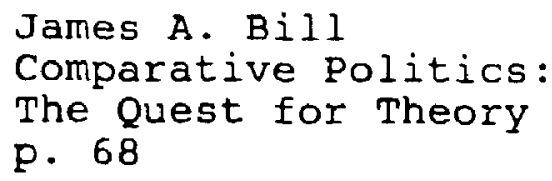

On 22 February 1988, Government Leader Dennis Patterson tabled a document in the Legislative Assembly of the Northwest Territories (N.W.T.L.A.) entitled pirections for the 1990s. Directions places great emphasis on the challenge of the political development of 
the N.W.T. The phrase "political development" is widely used in the N.W.T. and among those who study Northern politics. It is the aim of this chapter to show, first that there exist two competing schools of thought regarding the meaning of poljtical development in the N.W.T.; and as a consequence, there are different understandings of what factors determine a state of "high political development". The second goal of this chapter is to draw upon theory from the field of comparative politics to determine which of the two understandings is the more approgriate framework for discussing the pulitical development of the N.W.T..

Political development in the N.W.T. can be visualized in two different ways. First, political development can be seen as a train, departing from colonial status, making the same trip down the welltravelled track of the Euro-Canadian parliamentary model of responsible government and heading, as did Upper and Lower Canada, or later Alberta and Saskatchewan, towards the destination of provincehood. On the other hand, the image may be of a train travelling along the track according to its scheduled stops (to pick up certain new powers) originally set out long ago by people in Britain and ottawa, while simultaneously there are members of new generations trying to build a number of side tracks onto which the train can be turned. For them, the challenge is 
to complete the construction of those tracks and to gain control of the steering and consequently, to change the direction of N.W.T. politics. These two different visions of northern political development are reflected in both the scholarly literature and other perceptions, which will now be examined.

Early scholars of political development in the N.W.T. examined only the traditional track of the EuroCanadian model of responsible government and the progress that the Government of the N.W.T. (G.N.W.T.) had made along this path. This perspective is not suprising as it was the only track of development of which early schclars were aware. The classic study tracing this progression, which is otherwise known as the "evolution ol responsible government", is contained in the book, The struggle for Responsible Government in the Northwest Territories $1870-97$ by L.H. Thomas. He desct:s the final chapter of the second edition of his look to an examination (not contained in the first edition) of the Yukon and the present N.W.T. with respect \pm 0 their evolution along the path of responsible government--the pa:h which he had outlined and documented in the previous nine chapters of the book in his study of the evolution from territory to province of the provinces of Saskatchewan and Alberta.

In the Euro-Canadian model, a colonized area is 
established as a territory and is ruled initially by an appointed governor or commissioner and some public servants (councillors) in a metropolis quite far removed from the territory. The number of appointed councillors to the commissioner increase throughout the years with some appointments eventually chosen from among the people living in the territory itself. Elected members are gradually included to the point where a "territorial council" is formed and the opinions of elected representatives may be taken into consideration when the commissioner and his councillors make decisions. Through the years, power gradually shifts from the metropolis to the territory, finally to an extent where there is a fully elected Legislative Assembly no longer guided by neither a qovernor nor a commissioner but rather by a Government Leader and his Cabinet who enjoy the sustaining vote of the public and a majority of those holding seats in the Assembly.

In addition to Thomas's work, one can find an accurate account of the N.W.T.'s evolution according to the Euro-Canadian model, in "The srowth of the N.W.T. Government" by John Bovey [1966]. Morris zaslow has brought the evolution of the model up to the date of 1980, in The Northwest Territories 1905-1980. These are the major pre-1980 scholarly works documenting the evolution of the model of responsible government in the 
N.W.T. .

This type of analysis has been carried on in the $1980 \mathrm{~s}$ by scholar Michael Whittington [1981]. In "Canada's North in the Eighties", he measured political development in both the Yukon and the N.W.T. according to the progress that the political institutions had made "along the road to responsible government" [Whittington 1981:55]. Because the N.W.T. had not yet adopted certain institutions according to the model (for example, an official "Cabinet", party politics, and a more symbolic role for the Commissioner), Whittington made the judgement that: "The Northwest Territories has not progressed as far as the Yukon..." [Whittington 1981:55]. He concluded his article by saying that in the yukon "there is a higher level of political development... than... in the Northwest Territories" [Whittington 1981:66].

Hence the pattern set by the decolonization of Canada and the formation of the provinces of Alberta and Saskatchewan, was accepted by the first school of thought as the appropriate measuring stick for the political development of the N.W.T.. The concepts and generalizations that arise from Thomas's observations were assumed to apply to all developing territories within Canada.

However, what was thought to be political 
development on the part of these scholars, federal and territorial governments ${ }^{1}$, and some rather vocal residents of the N.W.T. who had a Euro-Canadian heritage, was strongly challenged by the Native peoples in the late $70 \mathrm{~s}$ and early 80s. The Native movement gained great momentum by the mid-70s and the inadequacy of the "southern Canadian" model of government became clear when the Natives' version of northern history was revealed.

The Berger Inquiry did much to bring Native sentiments about the government in the N.W.T. to nonNative public attention. Although the Berger Inquiry was given the mandate to establish the terms and conditions for building a pipeline (as opposed to a mandate to specifically study political development), Berger's discussion with the Native people in the western N.W.T. brought to his attention the Dene's rejection of the Euro-Canadian model of government.

After Berger listened to the Native people of the western Arctic, he drew two rather important conclusions [Berger 1977:175]:

1. "In developing institutions of government in the North, we have sought to impose our own system to persuade the Native people to conform to our political models."

2. " To understand why Dene and Inuit models have not been used to develop local and regional government in the North, we have to look closely at our own assumptions about the Native people. During the past few years, the Native people have challenged the validity of these assumptions." 
In 1981, there was a new argument and interpretation of political development for the N.W.T. presented by scholar Gurston Dcrks. He argued that political development is:

"...the ability to perform the political function. It is the ability of the members cf a society to make and implement effective binding decisions on goals accepted as legitimate by members of the society" [Dacks 1981:89].

This new school of thought is reflective of the Dene's deep dissatisfaction with the Erzo-Canadian style and system. The G.N.W.T. was losing its effectiveness to perform the political function because the Natives were challenging the legitimacy of the L..W.T. and its goals for northern society. In 1975, the Dene declared that:

"...the Government of Canada is not the government of the Dene. The Government of the Northwest Territories is not the government of the Dene. These governments were not the choices of the Dene, they were imposed upon the Dene."[Watkins 1977:4]

The new school of thought does not equate institutional development, according to the Euro-Canadian rodel, with political development but sees the latter as determined by two factc's. The first factor is the legitimacy given by the people to the institutions created. The second factor is the appropriateness of those institutions to the societies they are intended to serve. Dacks comments that with respect to the N.W.T. and the Yukon:

"Political development is not synonymous with 
institutional development. A political system is not necessarily highly developed simply because its government is structured along the complex, highly specialized representative lines that work reasonably well in many modern societies. Such a structure tends to promote political development, but only if it fits the society it is intended to govern. The government of both northern territories are cases in point. During the 1970s, they grew substantially, but this growth did not produce an equivalent growth in political development" [Dacks $1981: 90]$.

In examining the state of "political development" in the Yukon, Dacks's conclusion about political development contradicts Whittington's conclusion. Dacks points out that "the situation [in the Yukon] is the antithesis of political development because a political system can only be considered developed if the various groupings within it are reasonably well-integrated" [Dacks 1981:112]. The point made here, by Dacks, about the Yukon is also true for the N.W.T. where, in fact, the greater number of Natives living there result in a greater number of people not being reasonably well-integrated into the political system.

The Debate in Comparative Politics

This debate concerning political development may be relatively new to Northern Canada; however, it is not rew in the literature of comparative politics. James A. Bill explains that: "...the emergent nations of the Third World became ...laboratories for the analysis of social and political change, and the central concepts of this 
analysis came to be modernization and political development" [Bil] and Hardgrave 1973:43]. With Northern Canada and its large aboriginal population emerging from colonial status, it is easy to see that the North too would become a situation of interesting political change to which one could apply the concepts of political development and moderization.

The earliest theories in comparative politics about political development saw political change as unilinear; political develnpment was believed to have a foreseeable and predictable end:

"Like the nineteenth century social evolutionists, social scientists of the past two decades generaliy assumed that the advanced, liberal, democracies had 'arrived' and that their past mapped the course for other nations in their struggle for modernity" [Bill and Hardgrave 1973:49].

The logic that led to this understanding of development is explained:

"The concept of development is rooted in man's earliest attempt to understand change. The intellectual threads in the contemporary understanding of change extend back through twenty five hundred years of political philosophy.

The popular view of political development as stages of growth in inevitable progress only gives modern form to an understanding of change that has dominated western thought for centuries.

As man sought to explain change in society, he drew upon his observation of growth and development in plants and animals of 'change proceeding gradually, cumulatively, and irreversibly through a kind of unfolding of internal potentiality -- the whole moving toward some end that is presumably contained in the process from the start.' 
Growth, or development, is teleological. The origin of a thing, and the pattern of its change, is explained in terms of the end which it must, by its nature attain if unhindered by outside forces. Development, so understood is characterized by directionality, by genetically related stages following sequentially one necessarily out of the other, and by purpose." [Bil] and Hardgrave $1973: 43,44]$

This idea that political development had a Ioreseeable end -- the advanced liberal-democratic state -- was popular in the early days of political development theorizing. For example, scholar Richard Rose has considered England to be "an outstanding instance of political development" [Pye and Verba 1965:86] because of the following characteristics: widespread literacy, an extensive and penetrative network of mass communication media, extensive geographical and social mobility, a comparatively high degree of urbanization, a relatively high degree of commercialization and industrialization of the economy, comparatively high per capita income, widespread participation and involvement by members of the society in modern social and economic processes, socialization, recruitment, pressure groups, party system, political communication, and governmental machinery [Pye and Verba 1965:86].

Bill and Hardgrave have observed that "development" has been consiciered synonomous with western Europe and that the stages through which Western Europe proceeded have provided the pattern, or "map", for underdeveloped 
societies to follow. According to these authors, the theory of social evolution, which was popular in the nineteenth century, provided "a glorious justification for the ascendancy of the west in the imperial age" [Bil] and Hardgrave 1973:48]. Analyses of the political systems of Western Europe had resulted in a popular framework which saw development taking place through a number of "stages". Western Europe was seen as the pattern or map by which "underdeveloped" societies would and should progress from tradition to modernity. With time and encouragement from the West, it was felt that the primitive or traditional cultures would attain the modernity in the image of Europe. Non-western peoples were seen " 'as not simply exotic or different but as reflecting lower starges of an evolutionary advancement that was thought to be universal." [Bill and Hardgrave $1973: 48]$

Samuel $P$. Huntington argues that the identification of the concept of development first, with the Western, constitutional democratic state; and secondly, with modern life or with factors usually associated with moderization, "drastically limits the applicability of the concept in both time and space" [Huntington 1965:389]. He writes ${ }^{2}$ that a concept of political development that requires the condition of modernization: "...is defined in parochial and immediate terms, its relevance limited to modern nation states 
or the emergence of modern nation states. It becomes impossible to speak of a politically developed tribal authority, city state, feudal monarchy, or bureaucratic empire. Development. is identified with with one type of political system, rather than as a quality which might characterize any type of political system. All systems which are not modern are underdeveloped, including presumable fifth century Athens, the third century B.C. Roman empire, the $\operatorname{Han}$ and $T$ 'ang empires of China, or even eighteenth century America. None of these political systems was modern. Is it also useful to consider them underdeveloped? Would it not be more appropriate to consider development or underdeveipment as a characte:-istic which might be found in any type of political system? City states could be developed or underdeveloped; so also could be bureaucratic empires or modern nation states" [Huntington 1965:389-390].

Huntington challenges the idea that political development is identified with one type of political system, in Farticular the modern nation state. Instead, he sees development used more appiopriately as a concept describing a quality that could be found in any type of political system, modern or ancient. Furthermore, Huntington argies against the idea that political development is unilinear and irreversible. His observation is that many concepts of political development are usually "one-way", with little or no provision for their reversibility or the possibility of "de-development", which he labels "political decay" and characterizes with the following traits: political disintegration, institutional decline, domestic violence, authoritariansim, corruption and instability [Huntington $1965: 392-393]$. 
At this point, it should be said that some may feel that Huntington is open to criticism with his use of the words "development" and "decay" because these words, in fact, are concepts taken from the organic world conception of growth that $B i l l$ and Hardgrave criticize. However, Huntington escapes this criticism because he has a non-teleological view of development and decay, even if he does use "growth" related anologies.

Bill and Hardgrave, like Huntington, also distinguish the concept of political modernization from that of political development, regard them as theoretically distinct processes, and argue tnat political development is "most usefully understood in terms of a system's response capacity in relationship to demands" [Bill and Hardgrave 1973:66]. Distinguishing political development from political modernization is necessary for the discussion of the political development of traditional Native governments, which will take place in Chapter Two.

Many express agreement [see Bill and Hardgrave 1973:62] that there is no predetermined end or common outcome to the process of political development. Pye and Verba acknowlegde that an "understandable objection to the term [political development] is that it seems to imply certain value judgements which open up the danger that objective analysis will be confused with advocacy 
and idealistic preferences" [Pye and Verba 1965:11]. Furthermore, Sidney Verba feels that for a long time students of politics dealt with formal institutions they wanted to explain why a political system survived or failed, and why it was successful or unsuccessful. He counsels that one should look beyond the structures to the beliefs that affect the way in which people act within these political institutions [Pye and Verba 1965:514]. They maintain that:

"... political development strikes at the roots of a people's beliefs and sentiments about politics, and hence the process of development must be profoundly affected by the character of the political culture of a society" [Pye and verba $1965: 13]$.

Political culture, they argue, deeply affects the political development that will take place in a territory. This can be seen in the following example:

"A new constitution... will be perceived and evaluated in terms of the political culture of a people. When put into practise in one society it may look quite different from the same constitution instituted in another nation with another political culture. Similarly, political ideologies are affected by the cultural environment into which they are introduced. History is full of examples of constitutions that did not 'take' as the constitution writers had hoped because their application was mediated through a particular political culture, and history is full of examples of the ways in which political ideologies have been adapted to fit the pre-existing culture of the nation into which they were introduced" (Pye and Verba 1965:517].

A Canadian example where a "new constitution" (the 
fishing and hunting the large and small game that provicied them with most of the basic materials required for survival throughout the whole year: hides and sinews to make tents; furs to make various articles of clothing; bone, wood, sinew, and rawhide from which could be made tools and equipment such as knives, spears, snares, scrapers, needles, nets and snowshoes [Malloch 1984:9].

Activities such as "when anc' where to move camp and seek new hunting or fishing grounds, when and how to organize group hunts, how to define relationships with other groups of Dene in the area and ensure the safety of family or community" [Malloch 1984:13], required decision-making, leadership and government. Within each extended family group there emerged at least one recognized leader or headman, from among several people, recognized for particular abilities and strengths. The leaders were not formally elected or appointed but were "chosen" insofar as the other family members looked to the for leadership [Malloch 1984:13]. In the summer, several local bands would congregate at fish camps on lakes and rivers. This meeting of the "regional band" was a time for marriages, feasts and drum dances, all of which were "celebrations of life and unity which peole shared as a comunity in the summer season" [Malloch 1984:7]. But the gathering of regional band was also a time for leaders to meet: 
"In applying the analysis of political culture to the question of political development it is possible to throw light on the various combinations and constellations of values which may govern different patterns of development and which may be the prime cause of frustration and disappointment over the prospect of ...development" [Pye and Verba 1965:10-11].

That the Dene were frustrated and disappointed over the prospect of "development" in the North will be seen in Chapter Three.

\section{Political Development and Political Decay}

For many years, scholars, government, and many vocal non-Native residents of the Western Arctic have felt that political development occurs as institutional advancements go forth according to the Euro-Canadian model of responsible government. However, as Huntington pointed out, this approach limits the concept of development to identifications with the Western, constitutional, democratic nation-state and limits the applicability of the concept in both time and space.

If one separates the idea of political modernization from the concept of political development, then, one can conceive of, as Huntington suggested, "a politically developed tribal authority, city state, a feudal monarchy, or bureaucratic empire" [Huntington 1965:389390]. As a consequence, if we accept that to be "developed" does not necessitate being modern, then well- 
developed traditional Native governments can be discussed, which is the purpose of Chapter Two.

Huntjington argues that there is much to be gained in separating the concept of political development from the process of modernization and by, instead, defining political development "as the institutionalization of political organizations and procedures" [Huntington 1965:393]. He points out a number of advantages to doing so. The first is that the concept of development can thus be applied to the analysis of any political system, not just modern ones; secondly, it "can be defined in reasonably precise ways which are at least theoretically capable of measurement"; trirdly, a concept of political development which is not based on modernization no longer suggests that political change is likely to be in only one direction since institutions "decay and dissolve as well as grow and mature"; lastly, and most importantly, it focuses attention on the strength, stability or weakness of political structures, be they traditional, transitional, or modern. [Huntington 1965:393]

Once separated from the process of modernization, political development, now defined as "the strength of political organizations and procedures", can be assessed according to two fundamental criteria: first, the scope of support for these organizations and procedures; and secondly, their level of institutionalization. 
Scope is defined as:

"the extent to which the political organizations and procedures encompass activity in the society. If only a small upper-class group belongs to political organizations and behaves in terms of a set of procedures, the scope is limited. If, on the other hand, a large segment of the population is politically organized and follows the politically procedures, the scope is broad." [Huntington $1965: 394$ ]

Institutions are defined as "stable, valued, recurring patterns of behavior" [Huntington 1965:394]. It is explained that procedures and organizations can vary in their degree of institutionalization. An example given is that of Harvard University and a newly opened suburban high school; both are organizations, but the university is much more of an institution than is the high school. Institutionalization is explained to be the "process by which organizations and procedures acquire value and stability" [Huntington 1965:394] •

Four criteria are put forward to measure the level of institutionalization of any organizations and procedures of a political system: adaptability, complexity, autonomy, and coherence. The identification and measurement of these criteria allows one, according to Huntington, to compare political systems in terms of their levels of institutionalization. 


\section{A. Adaptability-Rigidity}

Adaptability is a characteristic of a political system that can only be tested through time; thus the age of a system and the number of challenges that a system has survived is a way of measuring the system's adaptability. Old organizations tend to be more adaptable than younger ones since the former, presumably, have had the opportunity to ousive more challenges to their existence. Nevertheless, old procedures and organizations cannot be characterized as adaptable if they have existed in a static environment. This is because an organization may have established a set of procedures for dealing effectively with one type of problem and finds itself unable to confront and deal with an entirely different type of problem.

of Huntington's criteria for assessing adaptability, there are a number which are met by traditional Native governments and which point to its strong institutionalization with regards to adaptability:

\section{Chronological Age}

With respect to chronological age, Huntington argues that the longer an organization or procedure has been in existence, the higher its level of institutionalization. The reasoning appears to be that 
the longer an organization has been around, the more entrenched it has become, and the more likely it will continue to exist. Traditional Native governments have existed for thousands of years. Thus, the great chronological age of traditional Native governments is a strong indication (or supporting argument) that they were highly institutionalized.

\section{Generational Age}

This is the second measure of adaptability. An organization which is still governed by its first set of leaders or by a procedure which is still in use by those who first performed it, has not yet been tested in its adaptability. However, organizations gain greater adaptability the more often they have "surmounted the problem of peaceful succession and replaced one set of leaders with another..." [Huntington 1965:396]. Throughout thousands of years that traditional Native governments have existed, each generation has succeeded in peacefully replacing the set of leaders before it.

\section{Functional terms}

A third way to measure an organization's adaptability is by examining how well it can change its function once its original function is no longer needed. The creation of an organization is usually for the 
accomplishment of a certain objective. When that objective has been fulfilled or no longer exists, the organization faces a crisis: either it finds a new objective or function, or readies itself to die. An organization which adapts itself to enviromental changes and has survived one or more changes in its primary functions is more highly institutionalized than one which has not. According to Huntington,

"...functional adaptability is the true measure of a highly developed organization. Institutionalization makes the organization more than simply an instrument to achieve certain purposes". [Huntington 1965:39?]

This is one point at which Native government was weak as it had not yet been tested as to its functional adaptability. For thousands of years, the function of Native government was to ensure the survival and selfsufficiency of the Natives. The traditional Dene way of Iife, for example, "changed little, except in response to the changes in the cycles of the earth and the seasons" [Malloch 1984:19].

\section{B. Complexity}

The simplest political system is one which depends upon one leader. Of course, it is also the least stable and the most likely to degenerate. On the other hand, a "mixed" political system, with various political institutions, is more likely to be stable ana adaptable 
if, for some reason, it suffers the loss of any one of its purposes or leaders.

In this way, traditional Native governments were strengthened by the diversity and diffusion of leadership roles. Although within each extended family group, there was one man recognized as the headman, leadership was not concentrated in this one person. Within an extended family, several people might be recognized for particular abilities and strengths. Different individuals were recognized as leaders in the respective areas of medicine, war, hunting, trading, and protection of the group.

Although traditional Native government is not by any means as complicated as "modern" nation-states or the provinces/states within nation-states, the political development of Native governments was strengthened by the diffusion of its leadership.

\section{Autonomy}

Although many necessary criteria for political development were met in traditional Native governments, the fulfillment of which helped lead to a state of effective political development in the pre-contact environment, there were some vulnerablities of traditional Native governments that would later contribute to a certain degree of political decay. One 
vulnerability was in the area of autonomy, or integrity of the political system. This means the degree to which the political system is "insulated from the impact of non-political groups and procedures" or the degree of vulnerability to outside influences [Huntington $1965: 401\}$.

\begin{abstract}
"In every society affected by social change, new groups arise to participate in politics. Where the political system lacks autonomy, these groups gain entry into politics without becoming identified with the established political organizations or acquiescing in the established political procedures. The political organizations and procedures are unable to stand up against the impact of a new social force. Conversely, in a developed political system, the autonomy of the system is protected by mechanisms which restrict and moderate the impact of new groups. These mechanisms either slow down the entry of new groups into politics, or through a process of political socialization, impel changes in the attitudes and behavior of the most politically active members of the new group" [Huntington 1965:402].
\end{abstract}

During the thousands of years that the Dene and Inuit were living in the N.W.T., they had neither experienced nor had to deal with the arrival of large groups of outsiders. In Chapter Three it will be seen how the lack of ability to enculturate the newcomers would have unfortunate consequences for Native governments.

\title{
D. Coherence-Disunity
}

What the Natives lacked in autonomy, was certainly made up for with respect to coherence and unity. "Numbers, weapons, and strategy all count... but major 
deficiencies in any one of those may still be counterbalanced by superior coherence and discipline" [Huntington 1965:403].

Coherence is that quality whirh cements together a group of people involved in politics since:

"...it is that willingness of most individuals to bridle private or personal impulses for the sake of general social objectives. Comrades must trust each other for the sake of general social objectives. Comrades must trust each other's ability to resist, the innumerable temptations that threaten the group's solidarity; otherwise, in trying social situations that desire to fend for oneself becomes overwhelming. The capacities for coordination and discipline are crucial to politics". [Huntington 1965:404]

The degree of consensus among the Dene and Inuit about values, principles, and philosophy of life is impressive. The values and principles of traditional Native governments will be examined in the next chapter. Again, many of the points that the Dene may have lost with respect to autonomy are won back because of the strong consensus on appropriate behavior and procedures that existed in traditional Dene society and government. There were few incidents of contested successions, of cleavages among leaders and members, of overt alienation an! dissent within the groups.

Summary

In this chapter it has been shown that within Canadian literature, there has existed two schools of 
thought about the meaning of "political development" in Northern Canada. An examination of some of the "development" literature from the field of comparative politics has shown problems with the use of the term "development" that have also occurred, understandably so, in the study of political development in the N.W.T.. Furthermore, in this chapter, a framework has been presented which allows for the occurence of not only political development but also of political decay. This framework opens the way for the following chapter's examination, of traditional Native governments as adequately developed political systems by studying the great degree of institutionalization of their political organizations and procedures. 
Endnotes

1. In addition to scholarly literature, there are a number of brochures and pamphlets, such as The council of the Northwest Territories, Northwest Territorjes Legislative Assembly 1979/80, and Ninth Legislative Assembly of the Northwest Territories, published during the $1970 \mathrm{~s}$ and early $1980 \mathrm{~s}$ by the Territorial Council of the N.W.T. (later becoming the Legislative Assembly in 1975) which update the "progress" that the Council/Assembly was making according to the responsible government model.

2. Of course, Bill's and Hardgrave's and Huntington's ideas, in turn, have been criticized by Marxists and others. For my purposes, however, the analysis of the three former authors is very useful. 


\title{
Chapter Two: Political Development
}

\begin{abstract}
"Have you ever thought of time as flowing like a river? Suppose the Mackenzie River from Ft. Providence to Inuvik represented the length of time that aboriginal people have been in the north. Then along the whole length of the river, it would be only in the last ten or eleven kilometres that nonNatives have come here. It would be only in the last four or five kilometres that Canada, as a country, has existed."

$$
\text { [W.C.F. 1984:no.4] }
$$
\end{abstract}

The aim of this chapter is first, to examine the traditional Native political systems which had been developing for thousands of years before the arrival of the Europeans; and secondly, to examine the very recent development of the Euro-Canadian model of goverrment which began shortly after the arrival of the Europeans, most of whom were involved in missionary work, the fur trade, mining and the R.C.M.P.. Before starting, it needs be stated here that there were differences within the broad groups that will be described and that the description to be given of traditional Native life will consist of what is believed to be general common features. Also, there is no intention to imply that there could not have been periods of growth and decay within Native societies before Europeans encountered them. However, as far as it is known, Native political systems seem to have been extraordinarily stable throughout time. Attention in this chapter is on the more persistent features of traditional Native governments. 


\title{
A. Traditional Native Governments
}

\begin{abstract}
"Anerica, separated from Europe by a wide ocean, was inhabited by a distinct people, divided into separate nations, independent of each other and of the rest of the world, having institutior.s of their own, and governing themselves by their own laws."
\end{abstract}

Chief Justice John Marshall

U.S. Supreme Court

1832

\section{Dene}

Traditional Dene decisiun-making took place among a people with a certain world view. They believed in the creator, that they came f:om the land upon which they lived and were part of the land and equal, not superior, to all living creatures. The earth provided them with all the necessities for survival and in return, "the earth and the cycle of the seasons made demands on the people, teaching them to practise certain ways of living that would ensure harmony between the Dene and the natural world" [Malloch 1984:7]. These ways of living, which will be further detailed, were crucial to the Dene's decisionmaking process.

Each Dene agreed that certain rules of nature "had to be followed in order to survive and that only by following set practices would harmony be ensured between the peciple and their env-ronment; thus, the objectives of 
traditional Dene government were clearly defined, since it was a society in which everyone shared a common view of the world and their place in it" [Malloch 1984:15].

The Dene believed that no one owned the land and that its gifts were to be shared by all creatures. The Dene saw their role as "caretakers" of the ear"h so that natural resources could be protected and continue to provide for the survival of the Dene.

The Dene moved about on the land in different sized groups, according to the changing seasons. The smallest group, the "band" or "local band" was the basic social unit and normally consisted of two to three extended families, all of whom "travelled and camped together, sharing the take of the large game in common" [Helm $1956: 138]$.

Except for summer, people travelled in local bands which varied in size from 25 to over 100 people, the average number in a group being 50 or 60 . In spring, for example, each band would set up camps to hunt ducks and geese migrating north, beaver and muskrat leaving their winter lodges and fish running upstream. In fall, local bands hunted ducks and geese on the migration south, picked berries, did fall fishing and prepared to move out to fall and winter hunting grounds where moose and caribou could be hunted. During winter, the local Dene bands travelled throughout their traditional territory 
fishing and hunting the large and small game that provicied them with most of the basic materials required for survival throughout the whole year: hides and sinews to make tents; furs to make various articles of clothing; bone, wood, sinew, and rawhide from which could be made tools and equipment such as knives, spears, snares, scrapers, needles, nets and snowshoes [Malloch 1984:9].

Activities such as "when anc' where to move camp and seek new hunting or fishing grounds, when and how to organize group hunts, how to define relationships with other groups of Dene in the area and ensure the safety of family or community" [Malloch 1984:13], requirsd decision-making, leadership and government. Within each extended family group there emerged at least one recognized leader or headman, from among several people, recognized for particular abilities and strengths. The leaders were not formally elected or appointed but were "chosen" insofar as the other family members looked to the for leadership [Malloch 1984:13]. In the summer, several local bands would congregate at fish camps on lakes and rivers. This meeting of the "regional band" was a time for marriages, feasts and drum dances, all of which were "celebrations of life and unity which peole shared as a comunity in the summer season" [Malloch 1984:7]. But the gathering of regional band was also a time for leaders to meet: 
"The headmen of different families would also talk amongst themselves about the seasons to come and the signs which the land and the animals were showing them. In time, the leaders of different families would make known to others their plans regarding when and where they would travel with their families in the fall and winter months of hunting." [Malloch 1984:7]

Leaders were "chosen" according to particular criteria. Since the Dene of the traditional lifestyle lived in what most Canadians would consider extremely harsh circumstances, in order to survive the Dene needed a keen understanding of their relationship with the environment, and they came to establish basic values and principles upon which decisions (political, economic, and social) were based to ensure survival:

\section{VALUES}

1. Sharing

The Dene shared in the use of the land and the resources of the land, in particular food. The work of maintaining the camp was shared, as was the responsibility for caring for children, and protecting the safety and health of the family.

2. Respect

One showed respect for oneself and for others, for leaders and elders and those with special skills, and for the land and all living things.

3. Caring

Caring was shown for all members of the extended family. The widows, orphans, and elders, unable to provide for themselves, were cared for and by their community. Concern was shown for the safety and protection of oneself and others in the home.

4. Equality

Equality among all people, and the equality of 
humans and all other living creatures, was recognized.

5. Self-Respect and Pride

Everyone, as equals, had reason to respect themselves and take pride in doing well whatever it was their particular responsibility to do. There was pride in being self-reliant, in being someone who could contribute something to the family and community.

\section{PRINCIPLES}

1. This land was created by "the one who provides for all", and we came from this land. We recognize our equality with this land and all living creatures.

2. We recognize and respect the natural laws which regulate the cycle of seasons, the rhythms of the earth, the ways of the animals.

3. No one individual has the right to own the land. As the ones who came from this land, we have a collective right to use the land and its resources to ensure our survival as a people. We also have a collective responsibility to protect the land and resources for our children and grandchildren.

4. We take only what we need from the land. We honour and give thanks to the spirit of the land and that which we take from the land. We do not waste anyrhing that we have taken from the land, but share it with all who are in need.

5. The survival of the whole group (family, community) is more important than the accumulation of individual wealth or status.

6. Individual rights and freedoms are respected and encouraged within the larger, more important context of a collective identity and collective responsibility for the survival and well-being of the entire group.

7. The laws of the Dene, which have been passed down to us by our elders, teach us how to respect the land, ourselves, and each other. They teach us how to live in balance and good health, and how to protect ourselves and our 
children. We must continue to live by these laws and pass them on to our children.

8. Respect and care for each other; in particular, honor and care for our elders, who cared for us and passed on the gifts of generations past. We also honor and provide for our children who will pass on the ways of the Dene to generations yet to come.

9. We come from male and female, and we respect and honour the contribution which both men and women make in working together for the survival of the people.

10. We respect and honour ou, leaders and medicine men and women who share their special ski.'ls, experience, wisdom, and powers for the benefit of their people. We don't expect them to work for us or serve us, but we look to them for guidance and instruction to help us govern ourselves in a good way.

11. Everyone has the right to be heard and to take part in the decision-making process or discussions which affect them.

12. We respect the right of Dene, in family groups, in communities, or in regions, to make decisions, without the interference from outside, with respect to matters which affect them alcne in their territory. [Malloch 1984:16-17]

The Dene encouraged a heal+hy self-respect and pride in one's ability to contribute to the group, but they neither condoned the individual accumulation of material wealth nor the search to rise above others in status or social position [Malloch 1984:11]. Rather, respect and positions of leadership were awarded to those who showed their concern for other people by sharing their gifts and skills with other family and community members [Malloch 1984:11]. 
These five values and twelve principles of life stated above are important to the Dene's way of governing themselves because leaders were chosen among those people whose life was well-grourded upon these values and principles:

"Leaders emerged from among those who demonstrated exceptional skill and understanding, grounded in their experience of life and the natural order. Men who possessed a particular ability to hunt and provide for the people, or those whose strength and good judgement served to protect the safety of the group, might emerge as leaders." [Malloch 1984:11]

Living on the land for generations had taught the Dene to work with the land, not against it. Fighting the forces of nature created more work and made their lives more difficult, and furthermore, risked the safety and suivival of the Dene. "For example, to attempt to move out on a hunt when the weather and snow conditions were not favorable, not only made the going tough, but also reduced the chances of success on the hunt anc put peoples' lives in danger" [Malloch 1984:9]. People learneu that there were certain laws that must be followed in order to survive and that they should have a balanced relationship with the rest of creation, and leadership was given to those who would follow these laws. To survive, they took from lhe land only what was needed. "To hunt more than wa:; needed, or to waste what had been killed, was to disobey the laws of nature and 
risk creating hardship for future generations of Dene" [Malloch 1984:9].

Although people were chosen as leaders, they were not accorded great decision-making powers. One of the basic principles of their political culture was that everyone had the right to be heard and to be involved in the decision-making process. The elders of the Dene Nation explicitly stated that leaders were to lead and guide, and not assume great decision-making powers:

"Although our leaders are very important to us, they are meant to guide us and not to have power over us.

Leaders have been givern special responsibilities by the Dene to lead, not assume dictatorial powers. It is the responsibility of leaders to have dialogue and debate issues, concerns, and laws with the people before formal decisions are maue.

The Dene way is very democratic because we talk things out until everyone agrees and there must be patience and respect for one another to do this. Under the struggle for consensus is the principle that we are all one and the circle must not break." [Malloch 1984:17]

Consensus decision-making was the style at level of the local band and the regional band. We are told that in traditional Dene society, when "the small family groups" which travelled and hunted "...faced...decisions, family members and in particular the elders, might take part in the discussions, everyone contributing their thoughts and feelings on the matter" [Malloch 1984:14]. It was generally accepted "that the leader or headmen of the family would draw from the discussion and from his own 
understanding a decision or course of action that would be followed by the group" [Malloch 1984:14]. Thus, in the family context, group discussion was involved in which the patriarchal leader would attempt to make the best. decisions, using the advice and opinions given in the family council, by which all family members would be willing to abide.

The summertime gatherings provided an occasion for the headmen of local bands to come to a consensus on policy for the regional band: "In the summertime, when several families gathered together at their fish camps, the headmen of different families would generally confer together when decisions were required which would affect the whole group" [Malloch 1984:14].

\section{Inuit}

Despite considerable attention from anthropologists, relatively little has been written regarding l'se way the Inuit governed themselves in traditional society. However, it can be determined that in traditional, precontact Inuit scciety three types of associations occurred throughout the year [Damas 1984:391]. From May to November ${ }^{1}$ there were summer hunting groups which varied considerably in size and composition depending on the ease or difficulty of foraging and hunting. If foraging was especially difficult and subsistence was 
reduced to hunting small game and fishing in lakes, the larger group would break down, for a few days at a time, into nuclear family groupings. Most often, in summer, people would stay together in groups of a dozen or more ( 2 to 3 extended families), when there was favorable caribou hunting or when fishing was especially good. In August, sites of the summer char runs allowed the largest summer aggregations, usually averaging about 50 people. In late autumn, a regular gathering of about 50 people took place during the "sewing period", so named because it was the time that the women would prepare winter clothing. Around the beginning or middle of November, at traditionally used points of land, the summer groups that hunted in a large, general area would gather to renew kinship ties and bonds of friendship.

The aggregation during the sewing period consisted of several extended families. Each extended family had a headman ("ihumataaq" for the Netsilik Inuit, "isrumatiak" for the Baffin Island Inuit) who was usually the eldest hunter in the extended family. The headman:

"...decided about the movements of the family, selected hunting sites, and advised the younger men on hunting matters and travel. No clear cut orders were given; the headman only advised and always consulted with the other hunters." [Balikci $1984: 422$ ]

Among the Iglulik Inuit, the camp that formed in the autumn, consisting of several extended families, usually 
had a leader called "isumataq". In general, he was "a mature and experienced man, who was a good hunter and the head of a large family" [Mary-Rouseliere 1984:440]. The isumataq was "the first among equals and only after consulting the other heads of families did he proceed to coordinate the activities, divide tasks, and sometimes distribute the game" [Mary-Roussiliere 1984:440].

The largest aggregation of the year occurred at large snowhouse settlements known as the winter sealing viilage. On average, 90 to 120 people gathered at a winter village from December until May. "The people of sealing camps were considered to be part of the regional -miut group" [Balikci 1984:422]. The availibility of seals for sustenance permitted the gathering of such a large group. It was practical to have so large a gathering. Each seal has a number of breathing holes and the greater the nunber of hunters watching any given breathing hole, in a given area, the better the chance for a speedy and bountiful catch.

In a large sealing village, several men would be designated as leaders. Among the Netsilik Inuit, the "elder hunters consulted informally on community matters with the opinion of the most experienced and prestigious elder carrying greatest weight..." [Balikci 1984:423424]. Steenhoven relates that among the Netsilik, although decisions to move elsewhere are left to the 
individual extended families, these decisions:

"...are often not taken without frequent previous visiting and countervisiting of each other and plans, opinions, and recent experience are thus exchanged. If a large camp sucuenly dissolves within a few days' time, there is most often a very plausible economic reason for it; and though the various families may spread in all direct,ons, each of them is well aware of the planned whereabouts of the other." [Steenhoven 1959:61]

According to Steenhoven [1959:56], leadership succession among the Caribou Inuit followed a certain pattern. Upon the death of a headman, the next oldest brother was to succeed the deceased as ihumatar. If the deceased headman had no brothers at the time of this death, the oldest mature son was to succeed. The new ihumatar, be it the brother or the scin of the deceased, took on the deceased's role as first, guide to younger brothers (or nephews) and their families; and secondly, supervisor of their important movements, trading policies, marriage arrangements, and the disposal of the deceased's important belongings, such as his kayak, hunting equipment and dogs.

Leadership succession could be swift, in the case of sudden death or could be almost imperceptible. For example, if the headman of the family became too old and untit and if he was also losing his mental superiority, he would gradually have to leave his leadership to his oldest son or brother.

Whether or not the mature and oldest son of a 
deceased inumatar would take on the leadership of the group or whether he would resign to his uncle being the boss depended upon the personality and ability of both. Futhermore, "...an oldest uncle or brother with too little personality or ability to give leadership [was] unlikely ever to become the ihumatar of his adult and skilful nephews or younger brothers" [Steenhoven $1959: 56]$.

\section{Summary}

An overview of the Native governments that existed before the arrival of the Europeans shows procedures and organizations that were heavily institutionalized because of the great chronological age and generational age of the political systems, the diffuseness of the leadership and finally, the great coherence of the respective beliefs of each society. In addition to being heavily institutionalized, the native governments also enjoyed a very broad scope of support.

\section{B. Euro-Canadian Government}

The political system which developed for the EuroCanadians was based on their political culture. Political development was seen as increasing the number of representatives to and increasing the amount of delegated authority from the central authority, the king or Queen, 
who was represented in the colonies by a governor. Political development was synonomous with whittling away at the monopoly of power initially held by the sovereign. The pattern can be seen for the Dominion of Canada itself and in the old North-West Territory for the case of Alberta and Saskatchewan, two sections of the territory which decolonized and gained provincehood in 35 short years.

On 23 July 1870, Britain accepted the concession by the Hudson's Bay Company of Rupert's Land and the Northwestern Territory and transferred these lands to Canada. These areas, which included today's Northwest Territories, Alberta, Saskatchewan, the Yukon Territory, most of Manitoba, and major portions of ontario and Quebec, were established as the Northwest Territories. Initially the Territory was governed exclusively $b_{y}$ a lieutenant-governor, chosen by the government in Ottawa. In 1877, the North-west Territory Council met for the first time.

During the next twenty-eight years, comparatively rapid constitutional development occurred in the southern part of the Territory where there was a concentration of settlers from Europe. In 1875, a provision was included for the election of members of the council. In 1888, a Legislative Assembly was established. In 1891, the deletion of appointed members made it a fully elected 
body. Finally in 1897, responsible government was achieved. Thus, the southern (European-settled) parts of the old N.W.T. had enjoyed responsible government for eight years by the year 1905, when Alberta and Saskatchewan joined Confederation as provinces. The crown was represented in each of the two provinces by a iieutenant-Governor but an elected Legislative Assembly with 22 members, led by an Executive Council, set policies and approved the budget.

After Alberta and Saskatchewan were created (in 1898, the Yukon had become a separate territory) the remaining Northwest Territories, in the eyes of the ruling Euro-Canadians, returned to the status of a colony governed from ottawa, as it had previously been in the early 1870s. Any settlers in the new N.W.T. were left to struggle their way to responsible government, as those in Alberta and Saskatchewan had done. Ottawa was once again the seat of government. The Lieutenant-Governor was replaced by a federally appointed commissioner who was responsible to the federal minister in charge of administering the N.W.T.. The Assembly was replaced, theoretically, by an appointed council (provision was made for a four member appointed council in the N.W.T. Act. of 1905) with limited powers and there was no longer elected representation.

In the new N.W.T., the gaining of representation and 
"be a minority region towed along by the larger Mackenzie population oriented toward the traditional development models of the south" [N.C.F. 1983:25].

The federal government responded to the political controversy developing over the issue of division by appointing an advisory commission on the development of the G.N.W.T.:

"The controversies which arose from the projected legislation for dividing the territories, and a growing appreciation of the complexities of providing government services to the widely scattered Metis, Indians, and Eskimos whose familiarity with existing and alternative forms of government varied widely, induced the government in 1965 to appoint an advisory Commission on the development of Government in the N.W.T., headed by A.W.T. Carrothers, Dean of Law at the University of Western Ontario." [Thomas 1956:282]

When Carrothers reported in 1966, he was aware of these issues in the Eastern Arctic, and recommended that division not occur at that time, but that the issue should be reviewed in ten years. He argued that what was necessary was "political development beginning at the community level... [because] it [was] feared that if the Nunavut area was cut loose from the dynamic Mackenzie, its political progress might falter" [N.C.F. 1983:25]. This advice and other key recommendations were accepted by ottawa. One notable recommendation was "the creation of a full-scale provincial style administration in Yellowknife, albeit retaining the regional offices which helped preserve some important sensitivity toward Inuit 
followed increases in the white population and economic productivity" [Thomas 1956:279]. John Bovey comments that the :

"...growing significance of the Council is demonstrated by the increasing frequency of its meetings during the $1930 \mathrm{~s} \ldots$... Annual meetings were a thing of the past; monthly meetings became the order of the day and they often had to be supplemented by special mettings to handle urgent subjects" [Bovey $1966: 41]$.

This influx of white immigrants, and especially the growh of the town of Yellowknife, "the industrial and commercial community that had sprung up... and was to provide the impetus for modernizing the institutions and society of the N.W.T." [Zaslow 1984:10], led to agitation for constitutional reform in the 1930s. The non-Native citizens of Yellowknife complained about taxation without representatior an Parliament and on the Territorial Council.

However:

- This entrepreneurial pressure was resisted in ottawa by a well-founded suspicion that an autonomous territorial government would be a white man's government and the interests of the majority of the population, the indigenous people, would be ignored." [Thomas 1956:278]

This is seen as an amazing sensitivity on the part of the federal government. While it is true that the political system in the N.W.T. was gaining importance in the eyes of the federal government because of its need to look after the increasing non-Native population, most Native 
people, who were still living on the land, were unaware of these political changes other than the effects the game laws were having on their hunting and trapping and which were causing them great hardships as a result.

In the 1940s, the federal government slowly gave in to local pressure. The last five ottawa-based commissioners, commencing with charles Camsell who had been born in che N.W.T., were "well-educated, sophisticated members of tiie bureaucratic elite, more aware than any of their predecessors of the aspirations and complexities of the situation in the North and the socio-economic position of the Indians and Eskimos" [ibid]. Thus, in 1945, when peace returned, "the time was ripe for a change of the form of government implemented in 1921" [Bovey 1966:42]. In 1946, J.H. McNivan, then manager of the Negus mine at Yellowknife became the first resident of the N.W.T. to be appointed to the Council. Bovey suggests that this was "to meet the political demands of the new community [of Yellowknife]" which had "pushed before the coun il a host of new social and administrative problems" [Bovey 1966:42].

Many writers on the North agree that significant changes to the structure of government in the N.W.T. did not begin until 1951, when amendments were made to the N.W.T. Act and the first three electoral districts in the Mackenzie district were created -. the Council was 
expanded to eight members (five appointed, three elected) and held two sessions a year, one within the N.W.T.. Both Dene and Inuit residents of the N.W.T. were allowed to vote in these elections, but the three councillors elected in 1951 represented the western district where, according to Thomas, "the articulate and discontented white immigrants were largely located" [Thomas 1956:279]. It was not until 1966, when a bill was passed in the federal Parliament to create the Central and Eastern Arctic and Keewatin ridings, that the Eastern Arctic gained any elected representation on council.

However, it was a breakthrough for "representative government" insofar as it was the first time since 1905 that elected members represented constituencies in the N.W.T. and again it was the first time since 1905 that the legislature had met somewhere other than Ottawa. The bill did receive criticism from members of the opposition in the House of Commons "because it was such a small step towards representative government" [Thomas 1956:279].

There appears to be some attempt at rectifying this situation of the Inuit not being well represented by starting a practise of alternating the N.W.T. Colncil sessions between the Western and Eastern Arctic:

"Two sessions of the Council were held each year, the summer ones in the north. Initially this affected oniy the Mackenzie Destrict or western portion of the territories. In July 1959, Council first met in the Eastern Arctic at Chesterfield Inlet on the west Coast of Hudson Bay. Thereafter it 
became customary for the summer sessions to alternate in the Territories between East and West. The practise of holding Coundil sessions sway from the seat of Government each year was continued until the establishment of the capital at Yellowknife in 1967." [The Council of the N.W.T. 1972:1]

Meanwhile in 1952, a separate federal constituency was created for the Mackenzie district; it was no longer included with the Yukon. The population of the Mackenzie district at this time was reported as 16,000 [Thomas 1956:281], a majority of which was Native. However, as only the non-Natives mainly tenefitted ${ }^{2}$ from the creation of the new constituency because the Canadian Treaty Indians were not enfranchised until 1960 [Thomas 1956:281] and of course, it is well-known that most of the Inuit live in the eastern Arctic, outside the electoral district.

with regard to the development of responsible government, Drury observed that the G.N.W.T. in the year 1951, had reached the second stage of the political evolution of the model, identifiable by the separation of the legislative and executive functions:

\footnotetext{
"In 1951, amendments to the federal statute that forms the effective constitution of the Northwest Territories (the Government of the Nurthwest Territories is a creature of Parliament subject to the will of Parliament, and is not secured in the provisions of the British North America Act) restored the form of government to approximately that of the second stage after confederation. The legislative and executive functions are now separated, but the commissioner
} 
presides over the council." [Drury 1979:25]

The year 1960 is hailed as one of significance. First, a change took place in the type of members appointed to the Council. Typically appointed members were drawn from the civil servants representing federal departments active in the North. But in 1960, three of the appointments were filled by people from the "private sector" [The Council of the Northwest Territories 1972:2] and only two came from the Federal civil service. The presence of the non-bureaucratic appointments was considered by the Ninth Assembly "to encourage a more independent view of the nature of the Council" [Ninth Legislative Assembly of the N.W.T. 1983:1.3]. However, it should be noted that appointments were made from the private sector, not the general public. No Native people were appointed, and yet they made up the majority of the population.

Due to the "rapidly increasing pace of development in the Northwest Territories, especially in the Mackenzie district", suggestions were made for even "more fundamental changes in the structure of Territorial Government" [Bovey 1966:42]. Thus, the second significant change took place: "the first fc:inal appearance of an issue which was still preoccupying N.W.T. legislators two decades later, the question of whether the North should be divided into two units, took place in 1961" [Ninth 
L.A. of the N.W.T. 1983:63].

In the January session of the Council, in 1961, Knut Lang of Aklavik introduced the question of dividing the N.W.T. into two territories, "in order to establish a resident and more autonomous government in the Mackenzie Valley" [Bovey 1966:42]. L.H. Thomas is no doubt quite right in asserting that the pressure for division "came from the white population in the Mackenzie district which expected that the western Territory (to be named Mackenzie) would make a rapid advance to responsible government" [Thomas 1956:281].

The attitude of the whites should be noted in the following description by Thomas of the territorial council's final resolution on the form of government:

"The [council] proposed that for both the western and eastern territories there be a commissioner and council with the same powers as those in the existing Northwest Territories. For the new Mackenzie Territory the commissioner should reside at the Territorial capital, and the council should consist of nine members, five elected and four non-resident appointees to provide experience and knowledge of administration, business and other affairs that may not be readily available in the territory. The other should bear an eskimo name, and its commissioner should live in Ottawa, assisted by an appointed council of seven, three of them residents of the territory, at least one of them an eskimo." [Thomas 1956:281]

However, strong opposition to division had come from many Northern residents. There was the fear in 1963, that "the Nunavut people (apart from those in the Delta area) had no vote, so in their new territory they might have 
been treated as an administrative problem rather than as a people taking charge of their own lives" [N.C.F. 1983:28]. The results of the 1964 Territorial election was evidence of this. The newly elected Territorial Council "quickly proved to be opposed to the policy of division advocated by its immediate predecessor" [Bovey $1966: 43]$.

The council members were not the only ones upset. We are told that:

"...there was vigorous criticism of the bills by some of the elected councillors, by representatives of a number settlements, some in the Eastern Arctic, by territorial members of Parliament, and by the outspoken judge of the Supreme Court, Jack sissons. The controversy raged for months, and the bills never passed beyond first reading." [ Thomas 1956:241]

The people in the Western Arctic who were pushing for change argued that first, the Eastern Arctic "was so different and would require so much unconventional development work that it would 'holi back' the Mackenzie which was presumed to be rushing headlong into an Alberta type boom" [N.C.F. 1983:24]; and secondly, that the Inuit were less politically developed than the Dene because "they had less contact with whites and still mostly used their native language" [N.C.F. 1983:24]. The Inuit were now feeling that the policies being pursued in the Western Arctic were not suitable for the Eastern Arctic, and they felt increasingly that the eastern Arctic would 
"be a minority region towed along by the larger Mackenzie population oriented toward the traditional development models of the south" [N.C.F. 1983:25].

The federal government responded to the political controversy developing over the issue of division by appointing an advisory commission on the development of the G.N.W.T.:

\begin{abstract}
"The controversies which arose from the projected legislation for dividing the territories, and a growing appreciation of the complexities of providing government services to the widely scattered Metis, Indians, and Eskimos whose familiarity with existing and alternative forms of government varied widely, induced the government in 1965 to appoint an advisory commission on the development of Government in the N.W.T., headed by A.W.T. Carrothers, Dean of Law at the University of western Ontario." [Thomas 1956:282]
\end{abstract}

When Carrothers reported in 1966, he was aware of these issues in the Eastern Arctic, and recommended that division not occur at that time, but that the issue should be reviewed in ten years. He argued that what was necessary was "political development beginning at the community level... [because] it [was] feared that if the Nunavut area was cut loose from the dynamic Mackenzie, its political progress might falter" [N.C.F. 1983:25]. This advice and other key recommendations were accepted by Ottawa. One notable recommendation was "the creation of a full-scale provincial style administration in Yellowknife, albeit retaining the regional offices which helped preserve some important sensitivity toward Inuit 
ard Nunavut" [N.C.F. 1983:25].

The government was advised to "gradually transfer powers to the north to create 'not provincehood, but the means of growth to provincehood"" [W.C.F. 1984: no.1]. Thus, in 1967, when Canada celebrated its hundredth birthday, the N.W.T. received as a gift, a new capital, Yellowknife, and the movement of the Territorial government to Yellowknife in 1967, with stuart Hodgson named as the first resident commissioner. 
Endinotes

1. The Caribou Inuit were an exception to this pattern. The meeting of their regional group took place in the summer, not the winter. Or in other words, the lifestyle of the Caribou Inuit was similar to the Dene lifestyle where the largest gatherings took place in the summer.

2. Some Native people benefitted at this time, as there were Metis and scme non-status Indians eligible to vote. 


\section{Chapter Three: Political Decay}

In the preceeding chapter, it was argued that there were many necessary criteria for political development which were fulfilled in traditional Native governments, the fulfillment of which, for centuries, maintained a state of political development in the pre-European contact environment. However, every political system has its strengths and weaknesses, and in this chapter it will be seen that certain vulnerabilities in traditional Native governments, although not critical before contact, later contributed to the degree of political decay that occurred upon increased interaction with the Europeans.

Before presenting the main arguments of this chapter, the working definition of political decay must be clarified. As stated in chapter one, Huntington characterizes political decay with the following traits: political disintegration, institutional decline, domestic violence, authoritarianism, corruption and instability. Thus, civil wars and coups d'etat would appear to be obvious signs of political decay and the result of what Robert E. Ward terms as the "critical mass of dissatisfaction ... [with] the political system as a whole" [in pye and verba 1965:65], which leads to revolutionary aspirations. Ward explains that in a complex political society where emphasis is placed on the 
government's output of tangible products such as regulations, goods and services, most people are more or less seriously dissatisfied with some aspects of government output and performance; and few, if any get all they want or feel they deserve. However, this tolerable and acceptable level of discontent nacds to be distinguished from the "critical mass of dissatisfaction" which leads to revolt.

Civil wars and coups d'etats have not occurred in the N.W.T., and they are not the signs for which to look when discussing the political decay of the Native and Euro-Caliadian systems of government in the N.W.T.. Rather, the signs of political decay in the N.W.T. consist of institutional decline, instability, and threats of domestic violence.

In this chapter, it will be argued that traditional Native governments moved from a state of development to a state of decay, signalled by institutional decline and instability, due to three main reasons: first, the existence of two intrinsic vulnerabilities, lack of autonomy and regulative capacity, of the Native political systems; secondly, the outside influences of disease and technology, which were thoroughly beyond Native control; and thirdly, the inability of Native governments to maintain a viable economy, which is an essential base for political development. 
In addition it will be argued that the Euro-canadian political system also experienced political decay, most dramatically from 1950 to 1975, which was signalled by institutional decline and threats of domestic violence. This is due first, to the systems' unsuitability for the political culture of the majority of people for whom it was to govern; and secondly, its unsuitable emphasis on non-renewable resource development for the basis of a "viable economy". This set of economic priorities held by the Euro-Canadian government, did not allow for great coherence and unity in the N.W.T. which, as pointed out in Chapter one, are two qualities in Huntington's framework that form an important component of political development.

\section{A. Serious Decay of Native Government (1922-1950s)}

The beginning of the fur trade had introduced an element of ease into the lives of the aboriginal peoples. An example of how the fur trade had eased the lives of some of the Native people can be seen in Gillespie's documentation of the case of a Mountain Dene woman who stressed the great difficulties experienced in tanning and sewing hides, especially that of the moose, before the arrival of metal knives, scissors, awls, and needles. Before the introduction of knives, hides were cut with beaver teeth or birds' beaks attached to wooden handles. 
Thus, before the availability of European trade items, the skins of sung or un-born calves were tanned whenever possible because they were more soft and easier with which to work. Also, adult clothing was made more oiten from netted ground squirrel. since those skins required no tanning. [Gillespie 1981:334]

Not only did the trade items ease the production of clothing and shelter, but they also increased economic security by aiding in the battle against starvation. It was difficult to kill, dry, and cache enough meat and fish throughout the year to feed the group during the weeks, or morths, of hardship. Starvation in winter resulted, in the pre-fur trade days, more from the difficulty of killing large game in winter rather than a scarcity. Gillespie explains that:

"During the summer and fall hunting, each major kill was at least, in part, sun-dried and cached for future use. Then the group would move on to the next predictably good hunting area. This pattern continued until November. During the wirter they would stay in a place as long as cached meat and freshly taken game supposed them. Then they wolld move on to the next closest cache from the sumnier hunt. Wright said it was very hard to kill ennigh animals throughout the year. Winter starvation apparently resulted not from a scarcity of large game but from the difficulty of killing it in winter. With tue scarcity of the snowshoe hare and the lack of large lakes where ice fishing was feasible. In the coldest nonths, the Mountain Indians had few resources other than large game for the lean mid-winter. With guns, he Mountain Indians found it mucn easier to kill everything, but most especially the moose. Even so, the muzzle-loading guns of the nineteenth century did rot prevent cases of winter starvation." [Gillespie 1981:332] 
Ihe fur trade brought ease, convenience, and increased security to the lives of the Natzves through only a slight adaptation of their traditional lifestyle which resulted in a seasonal visit to a trading post. Therefore, although "tie fur trade introduced many technological innovations to Native life and some dependence on manufactured goods, the people still lived on and from the land" [Berger 1977:143-144]. For the Dene, "partiripating in a trade economy... gave them access to the trade goods that had shaped a new standard of living" [Malloch 1984:21].

However, ihe fur trade also brought large numbers of foreigners, disease, and the market economy. As the Natives began participating in the fur trade, they could have foreseen neither the technology (steamboats, trains, bushplanes, gasoline boats and automobiles) that was to bring so many whalers, trappers, traders and miners into their homeland, nor the diseases that would arrive which their herbs and medicines would be unable to cure. Before the fur trade, the "atives had, what Michael Asch [1977:49-50] describes as, a "total economy". This meant that the regional groups among the Dene and Inuit were themselves completely self sufficient. This was accomplished "by organizing themselves into selfsufficient local groups within which production and distribution were collective activities" [Asch 1977:49]. 
If a certain local group was unable to maintain selfsufficiency because of scarce resources in its local. region, it would join with another local group fortunate enough to be having a surplus. Through the principles of cc operation and mutual sharing, the self-suffiency of the regional groups was maintained. However, as Natives became involved with the fur trade, the Native economy was transformed:

"...from a 'total economy' to one which relied both on local subsistence and the use of externally produced goods exchanged for furs.... Nonetheless, as a result of this economic shift... the standard of living was greatly raised. This must have made the people feel quite wealthy. This rise in the standard of living however, had an unexpected consequence: dependency. For now the stability and success of the Native economy was dependent in large measlire on external economic conditions such as high market price for furs in relation to trade good prices." [Asch 1977:52]

The first weakness of traditional Native government that became apparent is with respect to autonomy, and more specifically, the inability to enculturate the great number of white people which came to the canadian north. The Dene have written: "For thousands of years, our ancestors lived according to our ways, undisturbed untii the coming of the Europeans" [Dene Nation 1984:16]. Steve Kakfwi explains further that the Dene offered friendship and help to the Europeans, upon the latter's arrival:

"When non-Dene came to our land, we saw them as curious strangers who had come to visit; we shared with them and helped them to survive. We could not conceive that they would not see the world as we do. 
We trusted what people said, for that was the way we had lived amongst ourselves. The Dene had no experience or understanding of a people who would try to control us, or who would sav that somehow they owned the land we had always lived on." [Dene Nation $1984: 16$ ]

The Dene state that their early "acceptance of the white people... was natural" at the time of first contact, and feel that a comment given by an old Dene, Antoine Beaulieu, epitomizes Native sentiment at the time of contact. During court testimony in 1973, upon his being asked if the Dene did not like the arrival of more white people in 1900, Beaulieu replied: "We didn't mind. We didn't suppose they would bother us." [Dene Nation [984:16]

During the thousands of years that the Dene and Inuit were living in the N.W.I., they had neither experienced nor had to deal with the arrival of large groups of outsiders. Traditionally, population increases came from two sources: procreation within each band or the arrival of a few people or families from neighbouring bands. The socialization and integration of so slow, steady and limited a number was relatively straightforward. Children were easily socialized as they grew up within the group. Adults coming from other bands, had been previously socialized, in their childhood, to adopt the same values and principles which governed the lives of all the Native people. 
Thus no procedures were in place in the Native political systems to deal with the enculturation of large number of foreigners. The political systems were unable to enculturate the whites so that they would adopt the aboriginal view that people were "caretakers" of the land and "protectors" of the earth "so that the natural resources of the land would continue to provide for the survival of future generations..." [Malloch 1984:7].

These values were not shared by non-Native trappers who came to Dene lands in the early twentieth century. The devastating result of trapping by non-natives, who were unconcerned with conservation, was aptly described by L.H. Thomas:

"Trappers moved steadily down the Mackenzie River as far north as Arctic Red River denuding the area of furs. The Indians had no protection against the competition of the white trappers, and the Indians Agent at Fort Simpson reported in 1926 that many fur-bearing animals were practically extinct." [Thomas 1956:278]

As time went on and as more technological advances were made in the world, the North became nore accessible and attractive to outsiders. Thomas reports how technology brought strangers to the North:

"The discovery of rich deposits of uranium ore at Great Bear Lake and gold at Yellowknife brought hundreds of prospectors into the Territories and the establishment of successful mining operations. Steamboats began to ply the Mackenzie, followed by air travel (the twenties and thirties were the heyday of the bush pilots. Gasoline boats and radio communications also appeared." [Thoinas 1956:278] 
Malloch reports how the resultant surge in the nonnative population disrupted Native lifestyle:

"With the discovery of mineral and petroleum wealth in the north, there was a sudden infiux of prospectors and developers into Dene territory. The presence of these newcomers, together with the increased number of white trppers and traders inevitably had a disruptive influence on the traditional land use and lifestyle based on the land. Economic profit was the sole incentive motivating white trappers. The largely unregulated activity of white trappers, which included the use of poison baits and airplanes on traplines, contributed greatly to the fur and game famines which caused the Dene extreme hardship in the early decades of the 20th century." [Malloch 1984:21]

The social disorder wilch resulted from the lack of procedure for the enculturation of large numbers of foreigners was compounded by the second major weakness of Native government: the limitations of the regulative capacity. Regulative capacity refers to "the exercise of control over the behavior of individuals and groups" [Bill and Hardgrave 1973:71]. The Natives had war chiefs and warriors; however, in Dene and Inuit society where, first, the environment made it necessary for people to disperse themselves throughout the land in order to survive, and second, limited technology prevented the development of coercive political institutions, the Native system of goverment was weak with regard to its regulative capac:ty: "The dispersed population dictated by the environment and limited technology effectively prevented the development of coercive or complex 
political institutions" [Rogers and Smith 1981:144]. They had not developed a "police" force that could patrol so large an area.

A stronger and more widespread regulative capacity in Native society was inhibited by the Natives. dependence upon nomadic and migratory big game. Local and regional groups occupied vast areas, the range of which depended upon three important criteria: the anticipated movements of big game, the availability of lesser game in the area, and fisheries resources [Rogers and Smith 1981:14.]. Fumoleau also explains how the Natives lifestyle of subsistence living, left them vulnerable to exploitation:

\begin{abstract}
"The Indians were at a great disadvantage. They spent most of their time in the bush, without the opportunity to become familiar with the changes taking place around them. They were unable to react to these in any cohesive manner, leaving themselves vulnerable for exploitation and abuse." [Fumoleau n.d.:20]
\end{abstract}

Some may feel trat the weak regulative capacity was the result of a small vative population. On the contrary, anthropologists have recognized that large groups of Naives existed across Canada. These groups called nations, which consisted of several regional groups, were quite large. The Chipewyan nation consisted of approximately 4000 people [Rogers and Smith 1981:141]. The Chipewyans are only one of the seven groups composing the Dene. Rather the weakness would appear to come more 
from the fact that the nation rarely, if ever, assembled and that it was required to disperse throughout the land in small groups, so that the people could feed themselves:

"There is no indication that the "nation ever assembled... The regional groups or bands [ 200 to 400 people] were the largest entities that might but not invariably assemble for seasonal hunting and summer fishing, but they were usually dispersed in small segments for most of the year, particularly during the winter. As environmental conditions rarely permitted all the members of a regional band to assemble for a long period of time, its members were usually grouped into lesser segments, which may be called hunting groups, or local bands. They usually consist of a few nuclear families related through primary ties of kinship and marriage." [Rogers and Smith 1981:143]

The regulative capacity which did exist among the Native peoples, and which had the potential to develop, was undermined by the disease which the Europeans carried with them. The Chipewyan, as well as other subarctic and arctic peoples, were seriously affected by Europeanintroduced diseases. Hearne estimated that, in 1781 , nine-tenths of those Chipewyan trading in Churchill was wiped out by a smallpox epidemic [Hearne 1958:115].

Helm has written that one aspect of early contact which remained an enormous threat to Indian populations, until the modern era, was the arrival of new diseases, both chronic and epidemic: measles, scarlet fever, influenze, smallpox, tuberculosis and venereal disease. Starvation was often the result of epidemics as "the normally able- 
bodied were rendered unable to hunt, fish, and provide the other neccessities of life during the course of the disease" [Helm 1981:148].

Tuberculosis and smallpox were widespread. Duffy [1988:67] reports that tuberculosis was "the scourge of the Eskimo." There were also outbreaks of influenza epidemic in 1920 s with a particularly devastating influenza epidemic in 1928. Smith reports that as "late as 1948, a measles epidemic among the isolated Barren Lands band killed about 80 adults of a total of about 300 individuals..." [Smith 1981:273-4].

As hundreds of white trappers and traders moved into the N.W.T., the Dene government turned to the Canadian Government for protection from the social disruption and disease. The Dene understood the treaties to ensure first, "the protection of their aboriginal rights in the face of a growing white population in their territory" [Malloch 1984:20] and second, the provision of a medicine chest. In the second part of this chapter, it will be seen how the inaction of the federal government regarding its treaty promises contributed to the decay of the EuroCanadian political systems.

Another result of the fur trade, is that the consumer demands of the Natives had changed and the Native leaders were unable to meet these demands with the occurance of the economic crisis that resulted from the 
collapse of the fur trade. Dacks has commented on how this collapse adversely affected Native lifestyles:

"It was not the fur trade itself that hurt the Native people, but the collapse of fur prices that began in the $1930 \mathrm{~s}$ and lasted until the mid-1950s. Native people found they could not afford the goods that the trade had made available to them and on which they had come to rely." [Dacks 1981:34]

The drop in fur prices and the sudden increase in the price of consumer goods left the Natives with little or no bargaining power in the market economy. Duffy [1988:135] reports that in 1946 the Inuit were receiving between $\$ 15$ and $\$ 20$ for each white fox pelt, but by 1949 they were receiving less than $\$ 5$ and in some cases as little as $\$ 3.50$. Simultaneously, the Inuit faced great increases in the price of their essential goods. In rome cases, the cost almost doubled between 1946 and 1949. The important consequence of this event was that the Natives were unable to maintain a viable economy. It is impossible to be politically developed without a sound economic base. The Natives had hid a sound economic base before the fur trade, and during the initial years of the fur trade. Asch has written that in the early days of the fur trade the Native economy had changed little from its pre-contact state. In these early days, explains Asch [1977:49-50], the Native eccromy was still "total". The Natives as well, as the Hudson's Bay personnel depended almost exclusively upon local resources for their 
survival.

Fur prices continued to remain low throughout the $50 s$ and 60s; consequently, "people turned for support to the recently introduced government family allowances and old age pensions" [Malloch 1984:21]. With the drop of fur prices in the post-WW II era and the consequent collapse of the fur trade in the 1950s, the welfare state commenced to bloom in the North. Natives received family allowances and old age pensions. the federal government built nursing stations and schools; shortly thereafter, houses were supplied. The provision of all these things by the federal government gave it a pervasive influence over the lives of the Native people. Berger wrote that the Federal Government "of zered what few parents anywhere would ever refuse -- food, medicine, and education for their children" [Berger 1977:87]. The Canadian government brought many benefits to Dene and Inuit; in particular, greatiy needed food and medicine. Berger has also said that: "It is easy to discount these benefits now, but the attraction they held for the Native people, and the need the people quickly felt for them, soon became apparent" [Berger 1977:88].

However, there was a flip side to this political coin. Certain consequences for the Natives were attached to their acceptance of aid from the Canadian government:

"Northern natives entered a system whose object -- wholly benign in intent -. was to reorder their 
daily lives. Along with the introduction of health, welfare, education and housing programs came new political models. Municipal government, derived from Southern Canada was chosen as the institution for local government in the Native communities. We ignored the traditional decision-making process of the native people..." [Berger 1977:87]

\section{Summary}

In the 1950s, with first, high incidence of starvation; secondly, heavy financial losses suffered in the fur trade ad the consequent inability to maintain a viable economy as Natives had been able to do in the past; and thirdly, frequent outbreaks of disease with the consequent need and demand for medical care, the Native governments, due to scarce resources, were unable to meet the demands of their people. The procedures and organizations that had evolved in traditional Native societies were inadequate to meet these new needs and demands created by the new conditions.

As they accepted the Canadian government's aid in order to deal with these crises, this made then dependent upon another government system over which they had no control. The accompanying loss of the Natives' autonomy and self-sufficiency has led to a loss of power on the part of traditional leaders. Duffy [1988:198] comments that among the Inuit, "[i]ndigenous leadership waned in light of the growing prestige of the external non-Inuit leaders." Dene elders have also commented on the change 
couldn't understand the procedure that was being carried out.

The outcome of the December election, where one Native person got on Council, was a real discouragement to the Native people of Fort Smith who wanted to try to participate within the present political structure. They saw that there was little hope that they could take effective part in it. They could not get the proper representation on the municipal council, because it is a foreign system.

The governing body that has been set up in Fort Smith to make local decisions was created not by the people of Fort Smith, but by the territoriai government through its municipal ordinance. It has been desigred particularly for the population of Fort Smith that have moved from southern Canada to Fort Smith. It's designed in a way that these people from southern Canada can get onto the municipal council and take part in it much more readily than the Native population can. The Native majority do not believe that eight or nine people should decide the future of the community. They believe that the future of the community should be decided by the community, by the long-term residents who are the Native people and the white people who have decided that they want to make Fort Smith their home and have an irterest in the community other than a monetary one." [Watkins 1977:123-124]

This example indicates the difficult $\ddot{z}$ experienced by the Natives with the concept of representutive government and with official, formal procedures for choosing a leader. The Euro-Canadian model of local government differs much from the traditional Native models in which leaders were "chosen" by a consensus that a particular individual was the best man to lead the group.

The Inuit, as did the Dene, also experienced problems with unfamiliar political institutions, based on repres sntative and highly structured government, as can be seen from the following study of Iqaluit: 
was lnsuitable for the Native politioal culture and consequently did not experience a corresponding increase of scope with the increased population it was supposed to govern. Secondly, the Euro-Canadian political system had its priorities unsuitably set on non-renewable resource development for the basis of a viable economy.

Superimposition of the Euro-Canadian Model

In the 1950s, after the fur prices fell and the native economy collapsed, the federal government, due to public pressure in southern Canada, felt it had to come to the aid of the Native people. However, aid was given based on certain assumptions:

"Federal policy in the North since the late $1950 \mathrm{~s}$ has proceeded on the assumption that the traditioual way of life was dying, and that Native people had no alternative but the adoption of the white man's way. The short-run solution to the northern crisis was the proviston of health and welfare measures. The long-run solution was the education of Native people to enable them to enter the wage economy.

The Native people who were still living in the bush and on the barrens had to live in the settlements if they were to receive the benefits of the new dispensation, and if their children were to attend school." [Berger 1977:87]

The political, economic, and social changes which the government expected to take place in the lifestyle of the Native people resulted in the 1950 s and 608 being a time of great confusion for the Native people. One can clearly discern the growih of the responsible government 
model, which many felt to be political development. However, for the majority of the N.W.T.'s population, the Natives, this was a time of disorientation and increasing alienation.

The growth of "responsible government" was leaving the Naitve people less and less responsible for their own lives. This was a great blow to a people whose lifestyle was founded upon the principies of being self-sufficient and self-governing. The feelings of relief, from the suffering and starvation endured by the Natives durirg the 1930s-50s, turned to feelings of confusion and finally, by the late 1960s, discontent.

Throughout the summer of Centennial celebrations in $196 \%$, the Dene told of how their communities vere brought together and the time was used to share common hopes and problems. The foremost probiem was the inability to effectively influence decisions that were so severely affecting their lives:

"Although we were the majority population in Denendeh [the Western Arctic], we were finding nurselves th lave less say in the administration and laws of our land. Every year more mines were discovered and opened, roads were built, parks proposed, oil and gas wells drilled without our consent or often our knowledge. The education system in the territories provided no room for people who were different. Our children were being taken away for the purpose of education, and were returned to us years later as strangers to their own land, culture, and farulies." [Dene Nation 1984:1?]

Frustration was growing with the regional director 
uf Indian Affairs who annually gathered the Dene chiefs in Fort smith for an advisory council meeting. The chiefs felt they were never heard because they ended up repeating their points year after year [Dene Nation 1984:19]. The meetings were forever abandoned in October of 1968, primarily because no longer was the Depart.nent of Indian Affairs to provide services to the Dene but the new Territorial administration was to provide them instead. By this time, the Dene realizei they had to do something more, that they had to ory nize and act:

"Our patjence has endured over a century, but by the late 1960s, clouds of discontent hung all over Denendeh. We came to the realization that patience was not enough it we were to survive as a natiun and as a distinct people. The only answer to our increasing loss of contiol over our lives seemed to lie in organizing ourselves, politically an economically." [Dene Nation 1984:20]

So the Dene urganized economically by implementing cooperatives, which had proved worthwhile in the Inuit communities. "The cooperatives, though not huge financial successes, helper, us to analyze our situation and to organize" [Dene Nation 1984:20]. The experierce gained from cooperatives also led them "into more efficient noiitical involvement later on" [Dene Nation 1984:20]. Many workshops and assorlations were formed to help the Dene to become more politically aware, more proud of their culture and more spiritualiy rene od [Dene Nation $1984: 20-21]$. 
In 1967, for the first time, the Dene saw the written texts of Treaties 8 and 11 and heard the translation of the treaties into their own Native languages. Many were shocked when they heard the written provisions of the treaty. For example:

"When Chief Vital Borsetrouge of ... [Fort Providence] was told that the treaty provided for a hundred square mile reserve for this band, he understood it to mean an allocation of one hundred miles by one hundred miles. He and other Dene leaders had been opposed to the establishment of reserves; low their opposition was strengthened when trey realized how small it would be -- ten miles by ten miles!" [Dene Nation 1984:22]

In January 1968, Louis Rabesca of Fort Rae and three assistants began collecting recordings of Dene from Fort Rae and Fort Providence who had been present at the signing of Treaty 11. In July 1968, when the regional director of Indian Affairs made his annual visit to the Dene communities to once more explain to the people the treaty they had signed in 1921, the Dogribs of Fort Rae and their chief Jimmy Bruneau "boycotted the annual treaty ceremony until the government officials recognized that they had never given up their land and that the treaties were only peace treaties" [Dene Nation $1984: 22]$

Disgust with and resentment towards the federal government because of its paternalistic attitude towards the Dene and the obvious deception and misunderstanding concerning the treaties, led the Dene to believe that 
"'the best thing to do would be to tell the government i.sw to do things, and not let the government tell them" and that "'the Indians of the Northwest Territories needed some kind of formal organization" that would be "'a closer liason between all the bands in the territories'" [Dene Nation 1984:22].

This led to the birth of the Indian Brotherhood of the Northwest Territories in October of 1969 (later to become the Dene Nation). The Inuvialuit and Inuit were reaching the same conclusions; the former created the Committee for Original Peoples' Entitlement (C.O.P.E.) in January 1970 and the latter formed their national Inuit organization, Inuit Tapirisat of Canada, also at the beginnings of the 1970s. At this time the N.W.T. Metis Assocation also formed. These organizations aim to uphold the rights and interests of the Native people of the N.W.T. and give a voice to the opinions of the people.

These organizations helped the Native ceople to politically organize in their own manner and give voice to concerns that were arising over the effects of the implementation of southern style practices in the North. For example:

"Under Stuart Hodgson, the commissioner of the Northwest Territories since 1967, southern-style settlement or hamlet councils were organized in each village, which proved to be harmful to our own political structures. This led to further distrust uf the territorial government." [Dene Nation $1984: 25-26$ ] 
The establishment of settlement councils by the federal government undermined the traditional modes of selecting leaders.

In the meantime, the territorial government rapidly began to grow in its number of employees and programs. In 1970, a 10 person Assembly was created, six people were elected and their terms were extended to four years. But by the mid-seventies, "it became clear that many residents, especially the original peoples, did not see the Territcrial Government as their goverrment" [W.C.F. 1984: no.1].

What had gone wrong? Many felt that so mich progress had been made with respect to political development. But the problem. was that th model was imposed upon political systems that were still heavily institutionalized in Native society, and had been working well for the people for thousands of years, before the crisis period of the $1920 \mathrm{~s}-1950 \mathrm{~s}$. The old system was rejecting the new model in the same way that the body rejects alier substances placed in it. The model:

"... assumed that the people were not ready to exercise the political rights which canadians believe all peoples have, namely rights to express their preferences about essential matters of food, shelter, livelihood, language and opportunities for their children. Inuit and [Dene] had always had that power, but in the postwar period they temporarily lost much of it while a southern administration creatid a wholly new society around them." [N.C.F. $1983: 28$ ] 
The problem was essentially that "political history was being played out by people in ottawa and people in Yellowknife, few of them elected to office and none of them from the Native population majority in the territories" [N.C.F. 1983:31]. Carrothers saw this problem but his solution was to establish local government structures to give the Natives a political education so they could fit into the white man's model. Plans were laid out to stimulate greater participation in municipal government and to train the Native people "in the forms of liberal democratic self-government" [Abele $1987: 313]$.

Great problems were encountered by the attempt to have Native people switch over to a totally different model of government at the local and territorial level. The following (edited) account by George Kurszewski and Gerry Cheezie, in which they discuss the attempt of Natives in Fort smith to participate in an alien political structure, shows the inadequacy of Carrother's solution. The problem not only exists in Fort Smith, but in other communities as well, where there exist. "town councils" and not band councils.

"The council is made up of eight ccuncillors and one mayor. Four of thesc positions were open on 8 December. Six Native people ran for these positions and five white people ran.

Even though the Native people of Fort Smith make up 60 percent of the population, they did not come out to vote. There were a lot of problems in the election because a lot of the Native people 
couldn't understand the procedure that was being carried out.

The outcome of the December election, where one Native person got on Council, was a real discouragement to the Native people of Fort Smith who wanted to try to participate within the present political structure. They saw that there was little hope that they could take effective part in it. They could not get the proper representation on the municipal council, because it is a foreign system.

The governing body that has been set up in Fort Smith to make local decisions was created not by the people of Fort Smith, but by the territorial governnent through its municipal ordinance. It has been desigred particularly for the population of Fort Smith that have moved from southern Canada to Fort Smith. It's designed in a way that these people from southern Canada can get onto the municipal council and take part in it much more readily than the Native population can. The Native majority do not believe that eight or nine people should decide the future of the community. They believe that the future of the community should be decided by the community, by the long-term residents who are the Native people and the white people who have decided that they want to make Fort smith their home and have an irterest in the community other than a monetary one." [Watkins 1977:123-124]

This example indicates the difficult $;$ experienced by the Natives with the concept of representative government and with official, formal procedures for choosing a leader. The Euro-Canadian model of local government differs much from the traditional Native models in which leaders were "chosen" by a consensus that a particular individual was the best man to lead the group.

The Inuit, as did the Dene, also experienced problems with unfamiliar political institutions, based on repres sntative and highly atructured government, as can be seen from the following study of Iqaluit: 


\begin{abstract}
"By the 1950s, the population had grown to over 1500 people, over half of which were Inuit. This fict, along with an increasing interest in active Inuit involvement in government by the authorities, facilitated the establishment of a community council. This body, however, 'faced problem= due to the Inuit's unfamiliarity with the concept of representative political power and structured democratic organizations.' Breakdown of traditional structures by paternalism had taken away initiative from the Inuit and they were thrust into the cold of modern political life with no knowledge of it, much less a common support structure, or transition period. In 1965, Honigman wrote that 'the council ... has slightly disappointed administrators in failing regularly to solicit opinions from the people it represents'." [Swalm 1984:11-12]

Other authors have written why the Inuit of the
\end{abstract} Eastern Arctic were experiencing difficulties with the Euro-Canadian political system. For example, Duffy [1988:200] points out that a basic problem was the imposition of the rigid, bureaucratic structure of a southern model of decision-making upon communities where "traditional flexibility and consensus had previously governed Inuit decision-making." Hugh Brody [1075:18] notes that the Inuit had difficulties because of the growing colonial structures with which they were unfamiliar:

"... Canadian interest in the eastern Arctic had a typizally colonial aspect: land and people were insorporated into a growing political entity without rogard to the people's own wishes. Eskimos would indeed have found it hard to express wishes in the matter, for they had heard little of the institutions and less of the nation that was carrying out the process."

There have been problems with working in the 
Legislative Assembly as well. The following is an example from the experience of a Dene leader in the Eighth Legislative Assembly of the N.W.T., which did not have a corresponding representation ff the Native population as did the Ninth and Tenth Assemblies. The account by George Barnaby, of his own experience, gives insight respecting two problems that the Dene have with the Euro-Canadian model: first, the lack of decision-making power on the part of the general public; and secondly, the inappropriate division of powers between the Territorial level and the communitr level.

"These are a few examples of the culture of the Dene, the system of government, the laws, the way they differ from the southern system and people. The Territorial Council, from which I recently resigned, is one place where Dene law is not respected at all. There is very little irvolvement by the people; the laws that are passed have no importance for the people, but they are forced to follow these laws. The whole system is from the south, and they are trying to fit us into it.

Alot of times the topics that are being discussed are not understood. The language that is used is not understood. The frocedures and formality is confusing; most of the time, rather than look stupid, we just agree. As most of these discussions concern only the southerners, if they choose to live that that, it is up to them.

The first session of council I wert to, we spent two weeks on an ordinance that no importance to the people I represented. At this time I asked for more control for the communities. This was voted down.

At the second session of Council we talked of political development, where the council would have authority over the whole north. I spoke against this, as it would make no difference to the people; it still would not give them any rights to decide for themselves. The power would be only to the Council to decide the future of the North, and people would be forced to follow, whether they 
agreed or not. I think it was a plan to keep the people oppressed. We would get a land claim, but live under che laws of some one who has no concern for us or our wishes or our own laws." [Watkins $1977: 121]$

The account also affirms that the traditional method of Dene government is still important to the people and this fact no doubt contributed to the problems which arose in the Ft. Smith and Iqaluit examples given above.

Realizing that the real power in the N.W.T. was being weilded by the non-Natives, and that pressing Native concerns such as land claims and constitutional change were of little concern to and were often beyond the competence of the territorial council, the new Native nrganizations "concerned thcmselves with people's problems and found ways to tackle them" [N.C.F. 1983:36]. The territorial government maintained that "such bodies had no legitimacy" and yet the territorial government "still failed to open up the administration effectively to the interests and participation of Native peoples, preferring to hire more and more outside experts with more and more specialized qualifications to sort out the north" [N.C.F. 1983:36].

Initiatives were taken by the Native organizations to force the federal government to deal with Native concerns. A critical movi: taken by the Dene was the filing of a caveat, which was to be "a legal declaration that we have aboriginal rights to all of Denendeh, and 
that no decision about our land could be taken by the Canadian government without our consent" [Dene Nation 1984:26]. The decision of Justice William Morrow of the Supreme Court of the N.W.T. was the catalyst that Natives needed to get some action from the federal government. Morrow stated that first, "the 'indigenous people' were the owners of the land covered by the caveat and 'that they have what is known as aboriginal rights..."; and secondly, "that he doubted that aboriginal title to the land had ever been extinguished and that the caveators should be permitted to put forward a claim for title to the land" [Dene Nation 1984:26]. Furthermore, Judge Morrow "admonished the Car dian government that it had an obligation to protect the legal rights of the Native people" [Dene Nation 1984:26].

Meanwhile, the Nishga Indians of British Columbia were fighting for the recognition of their aboriginal rights and the resultant calder decision, in 1973, "suggested that aboriginal title might be a valid legal concept" [Dacks 1981:60]. Ottawa "admitted that aboriginal claims 'might' exist" [Dacks 1981:61]. Morrow's decision in combination with the decision of the Supreme Court of Canada recognizing aboriginal rights of the Nishga in 1973 put heavy pressure on the federal government to adopt a new policy with respect to aboriginal rights. Consequently, the office of Native 
Claims within the Department of Indian Affairs and Northern Development (D.I.A.N.D.) was established in July of 1974. The task of this new office was to prepare the federal government to negotiate claims.

The term "land claims" is a bit misleading. In fact, Bob Overvold, during his address to the N.W.T.L.A. in 1981, explained that land claims have never been, as they are commonly perceived, the negotiation for ownership of parcels of land:

"[For] years...we have lumped everything under the erroneous heading of "land claims". We are not claiming any land, the land is ours. What we are asking is that the federal government, in the name of Canada, recognize our aboriginal rights and negotiate with us a way in which those rights can be safeguarded so that our people and our culture can flourish, rather than be extinguished and die." [Overvold 1981: 1335-1336]

During the early 1970s, the intention of northern Natives in their land claims negotiations was to achieve selfgovernment, or in other words, separate aboriginal goveruments. This resulted in a separate political development process, outside the Territorial Council of the N.W.T., through land claims negotiations:

"Thus, there have been two separate political development processes going on at the same time, for the same area -- one fol non-native settlers through the Legislative Assembly and one for the aboriginal peoples through their own organizations." [W.C.F. $1984:$ no.2]

The unresponsiveness of the Territorial Council, combined with its inability to deal with important Native 
concerns, such as land claims and self-government, left the Native organizations feeling frustrated and angry and feeling that they had no choice other than to work outside of the Territorial Council/N.W.T.L.A.. These factors composed part of the context which led the Dene to make their "Dene Declaration" in which they rejected the Canadian government and the Government of the N.W.T.. The rest of the context, which was economic, will now be examined.

Conflict over Economic Priorities

Meanwhile in the 1970s, there was a crucial debate taking place, mainly within the forum of the Berger Inguiry, over the meaning of economic deveiopment and what would constitute a viable economy for the N.W.T.. Two fundamentally different philosophies of economic development were coming to battle before Justice Thomas R. Berger. The land-based, renewable resource-based economy of the Natives came into head-on conflict with the federal government's emphasis (reflective of the southern Canadian, non-native economy) on non-renewable resource extraction and industrialization as the basis for a viable economy.

Dene dissatisfaction with the priorities of the federal government goes back to the signing of Treaties no. 8 and 11 . The treaties had been an attemp by the Dene 
to create further political development. They knew that their regulative capacity vas weak and that they could not stop the white people from moving into their territory. Jonas Laviolette, chief of the Dene at Fort Chipewyan echoed in 1936, the same kinds of concerns that faced Natives befr:e the signing of the Treaties:

" 'We cannot do anything. White trappers sieal our trapping grounds. They remove our traps. There is nobody to protect us, and we cannot protect ourselves on cur own land against these invaders' ." [cited in Fumoleau n.d.:289]

The Dene had signed the treaties in an attempt to protect a vulnerability in their political system.

The Natives had understood the treaties to be agreements guaranteeing first, the peaceful and friendly co-existence of the Natives and non-natives; and secondly, their freedom to continue their traditional lifestyle. "Northern Indians signea Treaty 8 and Treaty 11 believing that the government guaranteed them freedom to hunt and trap, and would protect them from the competition of white trappers" [Fumoleau n.d.:235]. However, disappointment among the Dene quickly set in:

"The prospect of wealth in oil, minerals or fur lured adventurers North to explore this virgin country. The prospectors-cum-trappers offered the single greatest threat to the economy of the Indians. Contrary to Treaty promises that tho rights of the I.⿲dians to hunt and trap would be protected against the encroachment and competition of white trappers, these latter were permitted to exploit game resources ilmost at will." [Fumoleau n.d.:226] 

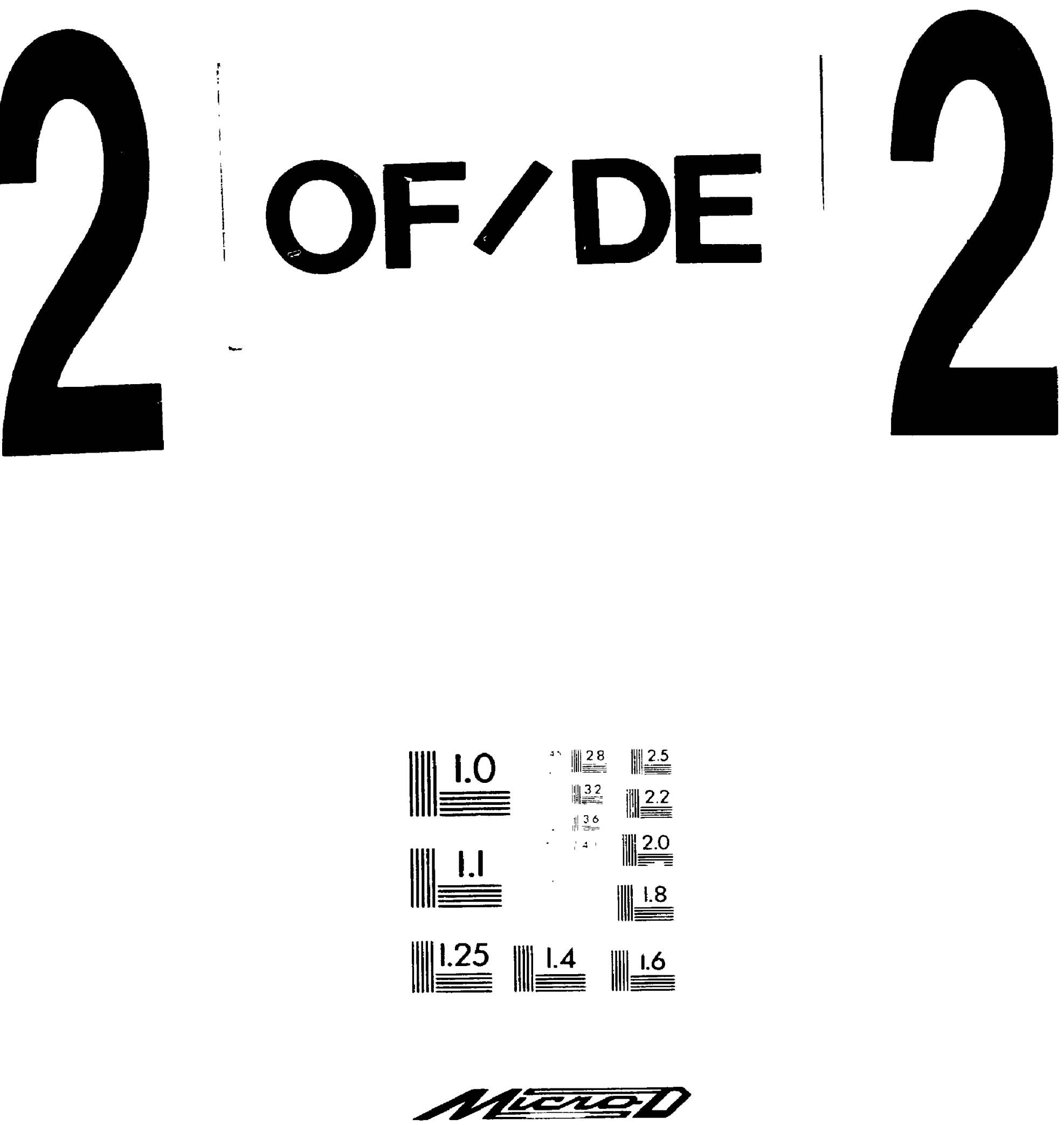
Disappointment grew as numerous letters, admonitions and entreatments to protect the Dene's livelihood from the exploitive and short-sighted non-native trappers, were ignored by the Federal government [see Fumoleau n.d.:2253081 .

The territorial council, to which was given delegated authority from the federal government, in tu:n failed to gain tha confidence of the Native people. The councils were soon seen "as the instruments of developmental interests rather than a means of achieving reforms" [Armstrong et al. 1978:120] which would have benefitted the Natives.

In 1921, when the federal government delegated some of the administration of the Mackenzie District to the appointed six member council, the council's policies were often contrary to the best interests of the Indian people:

Treaty promises made by the Federal Government were ignored by ... the territorial government.... Especially serious was the breach of promises to guarantee the Indian his freedom to trap and hunt, and to provide protection from the encroachment of white trappers. These promises were broken, forgotten, and finally disavowed, The game laws were often in direct violation of Indian rights, and caused hardships unequalled in Indian history. The Indians depended on trapping for 95 percent of their food. When these activities were threatened and restricted, it meant economic disaster for the Native people. [Fumoleau n.d.:20]

Treaty promises were ignored and priority was placed 
on non-renewable resource development. The federal government had long perceived the N.W.T. "as Canada's economic trump card and a treasure house of natural resources" [Parker 1989:3]. The result of this perception "has led the federal government to approach the North in a similar manner to that of Macdonald's 1879 National Policy" [Parker 1989:3] which had typically consisted of the metropolis's exploitation of the hinterland and its resources. According to Frances Abele [1987:310-311], the "National Policy" economic development strategy has persisted throughout the entire history of federal northern administraiion:

"In Diefenbaker's 'Northern Vision', the North was to be opened by means of a 'new Narional Policy'. The North, lilie the west 50 years earlier, would provide staple export commodities. Northern minerals, like western wheat, in an earlier period would fuel the engine of the national ecomony by providing export credits, jobs, and investment opportunities. The role of the state would be to facilitate resource development. A Territorial Roads program and a "Roads to Resources" policy were announced, a railway was constructed to Pine Point, and new oil and gas regulations were drafted to promote exploration." [Abele 1987:312]

With time, disappointment was compounded with disbelief and finaliy anger over the economic priorities of both the Federal and Territorial goveruments. Since the early twentieth century the primary renewable resource base of the N.W.T. had been increasingly threatened by various industrial projects encouraged by both these governments. Specifically these projects were 
hydro-electric power development, oil and gas offshore, mining industrial forest schemes, airports and military bases [Jull 1986:6]. The Mackenzie Valley Pipeline was the proverbial straw which broke the camel's back. The Dene, Metis and Inuvialuit were aghast at the rational of the federal and territorial governments. For example, at the Berger Inquiry, Frank T'Seleie commented and asked:

"You are coming to destroy a people that have a history of thirty thousand years. Why? For twenty years of gas? Are you really that insane?" [Watkins $1977: 16]$

A sense of desperation marked the voices of many Dene and the serious degree of political decay that had taken place in the N.W.T. was, in part, indicated by the option of violence that some Dene considered to be their last resort if the government continued its unresponsiveness. Phillip Blake voiced the frustration of these Dene, at the Berger Inquiry:

"If your nation becomes so violent that it would tear up our land, destroy our soziety and our future, and occupy our homeland, by trying to impose this pipeline against our will, then of course we will have no choice but to react with violence." [cited in watkins 1977:9]

The implication of violence was not considered, by the Federal Government, to be an idle threat. After the publication of the Dene Declaration, the R.C.M.P. worked undercover, until 1978, to infiltrate the Indian Brotherhood in order to assess whether rumours were true 
"that political 'radicals' were working with the Brotherhood and that the Dene were being trained in techniques of guerilla warfare" [Dene Nation 1984:29] .

\section{Summary}

The post war crisis in Native economy and Native society led to a serious degree of political decay in Native governments and also to the superimposition of the Euro-Canadian political system and political culture upon the Natives' respective system and culture. This superimposition, in turn, resulted in a serious degree of decay in the Euro-Canadian political system. This is due to :.ts organizations, procedures and beliefs being little suited to the majority of the N.W.T. population, which was Native.

The increasing inability of the Natives, since the signing of the Treaties, to influence the political and economic situations which were arising in the N.W.T. caused, by 1975, the political situation to come too close to a critical mass of dissatisfaction. By the mid1970s, "de-development" or political decay in the N.W.T. was approaching a state of crisis, largely due to the unresponsiveness of the Federal and Territorial governments. There are three main indicators of the state of crisis: the Dene Nation's severe disapproval of, and some of its members' threats of violence against, the 
Mackenzie Valley Pipeline project; the publication of the Dene Declaration; and the Dene Nation's boycott of the Territorial elections for the N.W.T.L.A.. The situation in the N.W.T. had not reached a critical mass of dissatisfaction but was dangerously close to it. 
Chapter Four: The Political Re-development of the N.W.T.

"Obviously, current northern society is not the same as traditional aboriginal society. There has been a loss of the total control once exercised. Resource development, the centralization into communities, the move from independence to dependence on government, the church, education, new technology -- all these and more have created a new reality. Cultures have evolved. The situation prior to contact no longer exists. At the same time, many of the traditions, values, and practices contilue, systems and forms are maintained." [W.C.F. 1984: no.4]

Native groups recognize that many circumstances, some of which are mentioned above and others which have been discussed in detail in Chapter Three, have resulted in a certain loss of control over their environment and in many changes to their traditional way of life. In spite of this, many of their organizations and procedures continue to be heavily institutionalized. Michael Asch affirms that "... despite our intrusions into virtually every facet of native society, traditional. economic, social, and political institutions and values persist and, in some cases, flourish" [Asch 1977:60]. Hugh Brody has written that among the Indit, in particular:

"Many of their ways -- economic, familial and individual are remembered and respected by the Eskimos of today -- and even by the young men and women who live under the hegemony of whites in the new Northern settlements" [Brody 1975:125].

Although during the first half of the 1970s, the Natives of the N.W.T. attempted to have a separate 
political development process for themselves in the forum of land claims, they later realized that efforts to create a political system which integrated Native goiernment and Euro-Canadian government would be more appropriato than pursuing separate systems of government:

"Each group has come to realize it cannot get much further on its own. Non-Natives cannot develop a government without respecting the rights of the aboriginal majority and at the same iime, the aboriginal peoples cannot develop a government solely through claims negotiations without public involvement" [W.C.F. 1984:no.2].

The result has been that "the Dene and Metis, as well as Inuit, are attempting to achieve aboriginal selfgovernment within public government... rather than separate political development" [Malloch 1984:1].

Political activity in the N.W.T. since the turning point of the late 197 s has revealed a number of essential criteria for future political development of the N.W.T.. These criteria have become especially clear as various proposals (the Nunavut Proposal, Denendeh Proposal, and the Consociational Model) have beer brought forward as suggestions for future political change. In this chapter, a discussion will take place first, of three major conditions which have set the stage for the political re-development of the N.W.T.; and secondly, of several criteria for political development which have been laid out, thus far, in the various models and 
proposals put forward in the search for political development.

\section{A. Conditions Contributing to Political Re-development}

\section{The Federal Government's Response}

The Berger Inquiry

The Berger Inquiry played a large role in checking the critical amount of dissatisfaction which was occurring in the N.W.T. during the early and mid-1970s.

Dosman has noted that the Berger Inquiry "was one of those rare Royal Commissions that generated public interest on a really significant level, and which therefore could influence the course of public policy" [Dosman 1978:135].

The Inquiry seemed to indicate that, at last, the Euro-Canadian institutions were becoming responsive to Native concerns. The Dene have written: "For the first time, we felt the Federal Government was serious about listening to northern people at official public meetings" [Dene Nation 1984:32]. However, the supposed "responsiveness" of the Federal Government appears to have resulted from some political arm-twisting:

"It is evident enough that the Trudeau Government's decision to appoint a Royal comnission to conduct a Mackenzie valiey pipeline inquiry, as well as the specific selection of Mr. Justice Thomas 
Berger, was born of the weakness of a minority government with heavy reliance on the N.D.P.." [Dosman 1978:138]

According to Dacks [1981:136], Ottawa knew that Justice Berge= was sympathetic to Native people, but Ottawa never anticipated how well Berger would conduct his inquiry in order to promote the cause of the Native and environmental groups interested in the Western Arctic. The Federal Government tried to limit Berger's impact by instructing him to " 'inquire into and report upon the terms and conditions that should be imposed in respect of any right of way that might be granied across Crown lands for the purposes of the proposed Mackenzie Valley Pipeline. " [cited in Dacks 1981:136]. As Dacks points out, since the project was already implicitly approved, Berger's mandate was not to advise the Federal Government whether or not the pipeline should be built but rather to determine the best conditions under which to proceed with the project.

However, decisions made by Berger, early in the Inquiry, fundanentally changed the final outcome of the Inquiry. Dacks [1981:136-137] expains that Berger redefined his mandate and built a political momentum that, consequently, made it very hard for ottawa to take lightly his recommendations. Berger announced that he would be considering the impact: 
"...not simply of a single gas pipeline, but also of a transportation corridor and of a gas-gathering system in the Mackenzie Delta as it might relate tu the pipeline. This decision flew in the face of the cabinet's wish to minimize the anticipated impacts of the proposed development." [Dacks 1981:136]

Also, there were groups wishing, but lacking the funds, to make detailed technical presentations during their testimony before Berger. These groups ultimately rezeived about $\$ 1.5$ million. Berger also ensured that all parties concerned had the information necessary to prepare their testimony by ordering that all technical studies of the proj.ct, whether done by government or corporations, be made public. He also arranged, in addition to the technical hearings, a series of community hearings in the Mackenzie valley and for public hearings in major southern Canadian cities. As Dacks comments:

"The first set of hearings enabled him to defend his findings by saying that he had gone directly to the occupants of the land to be traversed by the pipeline and by quoting their testimony. The publicity given the community hearings captured the sympathy of many Canadians for the native people whose testimony was extensively reported by the press. Berger could $n^{\prime} t$ possibly have provided the native people and particularly the Dene with a better platform for publicizing their positicn that there snould be no pipeline until their claims had been justly settled and implemented." [Dacks 1981:137]

The Drury Inquiry

The Federal Government realised, from comments made by many N.W.T. residents during the Berger Inquiry, that the status quo was unsatisfactory and that ronstitutional 
change was required. The challenge was to provide an appropriate forum in which discussion could take place. Land claims was not available as a forum because the Federal Government had expressed in poiicy statements on political development that structures and functions of government were not negotiable as part of the land claims. The forum of the Legislative Assembly was unsatisfactory since the Dene were unwilling to use the territorial assembly with which they were so dissatisfied; furthermore, as a result of their 1975 boycott tney lacked representation in the N.W.T.L.A..

The Federal Government offered a forum, in which it felt Natire concerns about the government could be voiced and dealt with, by appointing C.M. Drury as its special Representative for consultations, concerning political and constitutional development in the N.W.T., with leaders of the Territorial Government, Native groups, and communities. Drury's mandate was to seek consensus among the various groups with whom he consulted and to recommend measures to:

-modify and improve the existing structures, institutions and systems of government;

-extend representative, responsive and responsible government;

- transfer or delegate federal responsibilities and programs to the Government of the N.W.T.;

-promote native participation in government at all levels; and

-proiect native cultural interests. [Drury 1979:1] 
Although the Drury Report has been recognized as "an excellent survey of problems of political development in the north" [Dickerson 1982:457], its effectivess as a forum in which to discuss constitutional change has been severely criticized. The Dene rejecter it as impotent and unprogressive. They decider not to participate in the Drury Inquiry for two main reasons. First, they felt that "all relevant questions had been answered and discussed at the Berger Inquiry" [Dene Nation 1984:34] and that "Mr. Drury's mandate was to maintain the status quo and bury forever the landmark Berger report" [Overvold 1981:1341]. Secondly, they did not like the context in which the inquiry would take place. In 1977, shortly after the release of the cabinet document in which the appointment of Drury as special representative for constitutional development was announced, the Dene stated that:

" The Cabinet document suggests that there is no relation between political rights and the survival of a culture. Such a statement is absurb... How can a culture exist and grow without selfdetermination? ...the Casinet... endorses the view of the North as a frontier to be exploited, rather than a homeland..." [Dene Nation 1984:34].

Peter Jull has criticized the Drury Inquiry as being "too discreet to have an educational impact or to invite adequate support or feedback from the Native public" [Jull 1982:9], especially when compared to the situation in Greenland, where Natives there "were more involved in 
administrative reforms and especially in the transfers which have been occasioned by home rule" [Jull 1982:8]. Ir contrast to the N.W.T., "[i]n Greenland, a plan was negotiated between Greenlanders and Danes, discussed and lebated fully along the way through public information sessions and normal political processes, and put into practice" [Jull 1982:8].

As pointed out, the Drury Inquiry has been criticized as to its effectiveness as a forum in which to discuss change. Nevertheless, Drury did identify many of the major problems with the political situation in the N.W.T. and some discussion with Northerners did go on, although it certainly could not compare with the efiectiveness of the public hearings held during the Berger Inquiry.

\section{Increasing Organization and Solidarity of}

Native Organizations

The increasing organization and solidarity of Native organizations in the N.W.T. improved conditions for political re-development. Having gained a greater understancing of the functioning of Euro-Canadian political system, confident of their position concerning aboriginal rights due to the outcome of the various courts cases, and becoming determined to use their native majority to change the political system, the Native 


\section{B. Important Criteria for Future Political Development}

\section{Cultural Protection and Meaningful Participation}

To have continued on with the unmodified institutional evolution of the Euro-Canadian model of responsible government would not have led to political development. It neither provided for the cultural protection nor the meaningful participation of the Native people. These are two conditions of fundamental importance to the Dene, Inuit, and Metis. The following example, about the treatment of Native people in southern Canada and the until recent treatment of Native people in the N.W.T., attests to the fact that the model has not allowed for the meaningful participation of the Native people:

In 1905 when the southern part of the Northwest Territories became the provinces of Alberta and Saskatchewan, the aboriginal peoples of the region were not involved in deciding on the new government. As a result, the provincial governments spoke mainly for the settlers as did the Territorial Government established to administer the remaining N.W.T..

From this tradition, the Territorial council, now Legislative Assembly, has until recently approached political development without much concern for aboriginal lights and involvement [W.C.F. 1984: no. 2]

Not since the time of Louis Riel have the aboriginal peoples been involved in negotiating for the territorial or provincial administrations of which they are a part [W.C.F. 1984:no.3]. 
Assembly, that the current system of government be interrim until agreement was reached for a new system of government which was more in keeping with the desires of the people:

"It is the view of the Executive Committee that the existing Government of the Northwest Territories is a transitional government. Until such time as the issues of division and aboriginal claims are settled, this Government will maintain that position for the existing Northwest Territories" [A.R.\& C.D. 1981:(i)]

The success of Native people in winning a majority in the Ninth Assembly (1979) and in the Tenth Assembly (1982) has allowed the Natives to halt the continuation of the Southern Canadian model of responsible government down its traditional route. Witr the full entry of the Native people intr the territorial political process, the usual method of gaining responsible government, unlike the territories that had gone down the path before it, now involved the aboriginal people. In contrast to the past, now all N.W.T. residents, especially Native people, have the unique opportunity to determine the structure and style of their future government and the division of powers among the various levels of government.

\section{Response of the Territorial Government}

The Legislative Assembly has recognized from the report of its Unity Committee in October 1980, that people of the North, in particular the Native people, are 
"seriously alienated from the Territorial Government system which had developed" [N.C.F. 1983:46]. Although the Natives participate in the Territorial Government, there are problems trying to rule the western and Eastern arctic, two very culturally and geographically different areas, through one assembly. Primary reasons were the "extent of that area governed, and the different styles, hopes and conditions of the people in those two areas" [N.C.F. 1983:46].

The result of the Unity Committee's report was the formation of the constitutional Alliance. The Legislative Assembly stated its belief "...that the Aboriginal associations in the Ncrthwest Ierritories must participate fully in the process of politica. and constitutional change in their homelands" [G.N.W.T. 1982:1]. Thus, the Legislative Assembly forsook its leading role in "political developme'st and participated as an equal partner in the Constitutional Alliance. The twelve member Alliance consisted of two representatives from the four major Aboriginal associations (namely: the Committee for Original People's Entitlement, the Dene Nation, the Inuit Tapirisat of Canada, and the Metis Association of the Northwest Territories) and of four M.L.A.s, two of which represented the interests of nonNatives in the N.W.T. and two of which represented the N.W.T.L.A. . 
The Constitutional Alliance membership agreed to the following principles and objectives:

a) support for division of the N.W.T.;

b) a commitment to actively promote a yES vote in the April plebiscite on aivision;

c) the belief that initiatives for political and constitutional change must originate in trie North;

d) the desire to provide a forum to facilitate public participation in the process of political development;

e) the development of common positions and the negotiation of constitutional reform with the Federal Government;

f) the initiation of political and administrative reforms within the N.W.T. which are possible within the limits of the current N.W.T. Act. [Brockman and Iveson 1987:3]

On 14 April 1982, a plebiscite was held in the N.W.T., on the issue of division. When residents were asked if the N.W.T. should be divided, a overall majority (568) of the voters favoured the division of the N.W.T.. In the eastern arctic, 808 of those who voted were in favor of division.

With such a strong mandate to divide the N.W.T., the Legislative Assembly immediately accepted the results of the plebiscite and supported division. Nineteen M.L.A.s voted in favor, none voted against and one abstained [Brockman and Iveson 1987:4].

Furthermore, the Constitutional Alliance, which had agreed in February 1982 that its future activites would be guided by the outcome of the April plebiscite [Brockman and Iveson 1987:3], decided at a meeting held 
in July 1982 that two subgroups of the constitutional

Alliance should be created: the western Constitutional Forum (W.C.F.) and the Nunavut Constitutional Forum (N.C.F.). The role of each was to:

a) come to a clear position on the boundary between east and west and negotiate this with Ottawa,

b) develop detailed proposals for political and constitutional development for their respective territories and that they be prepared to draft new constitutions in the form of legislation,

c) accomplish both of the above with the help of public consultation processes which ensure tha: all major interests in the N.W.T. have the opportunity to participate,

d) plug into internal-transitional changes within the G.N.W.T. and,

e) negotiate their final proposals with the Federal Government;

[Brockman and Iveson 1987:5]

There are a number of reasons why the formation of the Constitutional Alliance, the W.C.F., and the N.C.F., was a significant step for the political re-development of the N.W.T.. Not only did this provide for greater public participation but it, for the first time, stressed and incorporated within its membership the equality of cultural groups, two of a number of important criteria for political development which will be further discussed in the following section of this chapter. 
B. Important Criteria for Future Political Development

1. Cultural protection and Meaningful participation

To have continued on with the unmodified institutional evolution of the Euro-Canadian model of responsible government would not have led to political development. It neither provided for the cultural protection nor the meaningful participation of the Native people. These are two conditions of fundamental importance to the Dene, Inuit, and Metis. The following example, about the treatment of Native people in southern Canada and the until recent treatment of Native people in the N.W.T., attests to the fact that the model has not allowed for the meaningful participation of the Native people:

In 1905 when the southern part of the Northwest Territories became the provinces of Alberta and Saskatchewan, the aboriginal peoples of the region were not involved in deciding on the new government. As a result, the provincial governments spoke mainly for the settlers as did the Territorial Government established to administer the remaining N.W.T..

From this tradition, the Territorial Council, now Legislative Assembly, has until recently approached political development without much concern for aboriginal lights and involvement [W.C.F. 1984: no. 2 ]

Not since the time of Louis Riel have the aboriginal peoples been involved in negotiating for the territorial or provincial adminibtrations of which they are a part [W.C.F. 1984:no.3]. 
The pattern throughout the years is typical:

Oyer the years, Canada has made agreements with various aboriginal pecples, and yet, regardless of how well-intentioned the dominant society may have been at $t>3$ time, effective guarantees have not lasted. In cime the pressure of increased settler populations or the lure of resource development has become more important. Aboriginal people are outnumbered and pushed aside. They may be given reserves on which they have some powers. However, with no real voice in the public government, they are isolated and ignored [W.C.F. 1984:no.3].

The loss of "real voice" is due to becoming outnumbered in the Euro-Canadian political system winich is based on universalism and the strict application of majority rule. The Euro-Canadian model does not recognize the equality of cultural groups. Rather, in a political system based on universalism, "the population is conceived to be organized solely on the basis of individualism and equality", or in other words, "seen as being composed of individuals who for all legal purposes are equal" [Asch and Dacks 1985:38]. There is a one person one vote orientation. No matter how large an original group may have been, when it becomes outnumbered, the result is that legislative control goes to that portion of the population which forms the majority. The voices of the original group become only a few of many and can be easily drowned out.

As mentioned in Chapter One, Canada has previously provided for the meaningful participation and cultural 
protection of francophones by drawing the borders of Quebec around the cultural group and by giving the provincial government power over jurisdictions that were felt, by the province, to be most important for it to control. Meaningful participation and cultural protection were ensured by the fact that the francophones were the majority of the population in the given area.

It is this same strategy that lies behind the Nunavut Proposal put forward by I.T.C.: "...all the Inuit are asking for now is a Yukon-like arrangement: a territorial administration" [Jull 1982:7]. The Nunavut proposal is based upon the division of the N.W.T. which would result in the Inuit being the majority of the population in the new eastern territory to be called Nunavut.

"In the new Eastern Territory, the Inuit will likely be a clear majority for some time to come. They will probably have a number of years to develop a style and structure of government which reflects their values and traditions, even if at the time of division they simply adopt a government pretty much like the present Government of the N.W.T.." [W.C.F. 1984:no.11]

The major risk with the Nunavut proposal is that should demographics change and more non-Natives șo to live in the Eastern arctic, the Inuit could become the minority cultural group in Nunavut and proceed to lose a "real voice" in the legislative assembly and in some larger communities where the non-Native population would 
be most likely concentrated. The gamble that Inuit are willing to take is based on the fact that there have been few things in the Eastern Arctic that have attracted large numbers of non-Inuit to live there. The hope is that the future will be no different and that no large numbers of non-Natives will arrive to upset the balance of power in a future Nunavut government.

The minority status of the Natives in the western Arctic necessitates a different strategy from that found in the Nunavut proposal. A future political system in the Western Arctic based on universalism and the strict application of majority rule would likely result in the fate which the the Natives in southern Canada have already suffered, the loss of "real voice" for Natives, in public government:

"... the strict application of majority rule... will likely lead ultimately to legislative control by the portion of the population that now forms (or at least may soon form) a distinct majority, the non-aboriginal.

Under these conditions, there is concern that the assimilative tendencies inherent in universalism as well as other factors may determine the ability of the Dene/Metis and Inuvialuit to retain and strengthen their cultural communities [Asch and Dacks 1985:42].

The strategy of the Dene and Metis is found in their 1979 proposal entitled "Public Government for People of the North", popularly known as the Denendeh Proposal. It calls for "the creation of a province-like territory to be called Denendeh which would protect the political and 
cultural rights of the Dene within one government system" [Kakfwi 1987:B2-B3]. There are four components of the Denendeh Proposal which attempt to ensure cultural protection of a Native minority in a future western Arctic territory. First, it was proposed "that a charter of Founding Principles be written which provides irrevocable protection for the collective and individual rights of the Dene and for the individual rights of other Canadians in Denendeh" [Dene Nation 1981:5]. Secondly, the Denendeh Proposal suggested that the native population be guaranteed 308 representation in the legislative body. Thirdly, the proposal included the creation of a Denendeh Senate tr.t. could veto legislation which it considers would adversely affect aboriginal rights:

In addition to the national assembly there will be a Denendeh Senate composed of Dene. The number of members on the senate and the way that they are selected will be determined by the Dene. The powers will include:

(i) the power to veto any legislation passed by any community council or by the national assembly if the senate determines that the legislation adversely affects aboriginal rights. The senate will outline its objections and return the legislation to the appropriate body. The revised legislation will be submitted to the Senate [Dene Nation 1981:17].

Fourthly, the Denendeh Proposal requested a residency requirement of 10 years in the N.W.T., before a person be permitted to vote or run for public office. The aim here was to help ensure that the political decisions having 
long-term consequences will be made by the people who will have to live with the reults of these decisions. The non-Native population of the N.W.T. is characterized by a high number of transients. Many people such as R.C.M.P. officers, teachers and nurses stay for only two years and return to live in southern Canada. The Dene and Metis do not feel that it is just when transients and/or people lacking the necessary sensitivity to and understanding of N.W.T. issues be permitted to participate in the making of policy with which the long term residents of the N.W.T. (most of which are Native) will have to live.

Since the Denendeh proposal of 1981, there has been a more recent discussion paper put forward by Michael Asch and Gurston Dacks concerning the relevance of consoniation to the N.W.T.. Asch's and Dacks's proposal is done in the spirit of developing the responsive capacity of the system to meet the new demands upon it by assessing the territory's particular liabilities and assets and trying to learn from those countries whose problems most closely ressemble its own. They draw on examples of such jurisdictions as Belgium and Switzerland where there is, as in the N.W.T., concern about assimilation, the strong desire for autonomy and organizing state institutions in a manner that promotes liberal-democratic ideals (this is a strong part of nonNative culture in the N.W.T.). 
The consociational model put forward by Asch and Dacks is based on the assumption that:

"... there is a willingness to find an accomodation for the concerns of the various cultural communities so long as this does not violate democratic values and does not create totally separate provincial-type jurisdictions for each cultural community with the region." [Asch and Dacks 1985:37]

The model provides for a territorial/provincial legislature in which decision-making is based on the principle of majority rule. However, the difference from the present Euro-Canadian model is that there would be certain legislative matters which would come under the control of particular cultural communities. These matters would not be subject to the majority rule of the territorial legislature.

"Consociation, as we are using the term, provides mechanisms to overcome the inevitable conflict that can arise when unbridled majority rule comes into contact with significant cultural communities within a jurisdiction. In brief, the mechanism accomplishes accomodation through dividing the powers of government in such a way that, while most matters are decided by traditional parjiamentary means, others that relate directly to the integrity of the cultural communities are decided in a manner that ensures the communities take responsibility for their own affairs and that they can veto changes in such arrangements." Asch and Dacks 1985:37]

The division of powers in done in such a way that the central authority, which operates with the one person one vote orientation, has control over the vast majority of legislative matters. However, the matters of primary 
importance to the cultural communities (such as education, the promotion and preservation of language, civil justice, some aspects of criminal justice, some aspects of economic development) are allocated to the "authority that acts to protect and enhance matters of primary concern to cultural communities" [Asch and Dacks 1985:381. In addition, certain constitutional and legisiative mechanisms, which are democratic in nature, "can block the imposition of strict majority rule upon certin matters conceived to be of vital concern to the cultural communities" [Asch and Dacks 1985:39]. For example, any change to the right of a cultural community to control education (for example, the choice of the curriculum and how it is taught) could only be made through a process preventing the imposition of the will of one cultural group upon another [see Asch and Dacks $1985: 45]$.

While Natives form a majority in the Legislative Assembly at the present time, if the demographics of the N.W.T. were to change in the future it is realized that the Native people may not have the same voice in the government as they now enjoy. The principle of meaningful participation, which the Denendeh proposal attempted to protect with guaranteed representation for Natives, the Denendeh Senate, the 10 year residency requirement, and constitutional protection of aboriginal rights, is 
protected in the consociational model by the mechanism of power sharing between the central authority and the cultural communities.

\section{Cultural Equality}

Cuitural equality has proven to be an essential criteria for political development in the N.W.T.. As has been pointed out, it was of primary importance when the membership of the Constitutional Alliance was chosen. In the Constitutional Alliance, two representatives were chosen from of the Native crge izations, from the nonNative population and the G.N.W.T..

Also, the importance of equality between the different groups in the constitutional process was discussed by former Dene President, Steve Kakfwi, on 9 June 1987, in a letter to all Dene chiefs and subchiefs. Kakfwi recolints that:

"The seconci motion passed at the Joint Leadership Meeting dealt with the process of constitutional development, particulary the fact that the aboriginal organizations must remain equal partners with government. Once again, skipping the whereases, this motion reads:

'THEREFORE, be it resolved that the Metis Association's Board of Directors and the Dene Nation's Leadership continue to support the Alliance as the only type of mechanism capable of legitimately and successfully addressing the issues of constitutional development, division and the selection of a boundary, and that any attempt on the part of the Government of the Northwest Territories or any other single party to aseert primary responsibility for this process will be rejected'." [Kakfwi 1987:B6] 
Cultural equality has also proven to be very important to non-Natives. For example, in "Public Government for People of the North", it was proposed that there be an Aboriginal Senate which would first, veto any piece of legislation passed by the Denendeh Legislature which contravened aboriginal rights; and secondly, if the Dene representation should ever fall below its guaranteed 308, determine the manner by which eligible Dene voters will elect sufficient Dene members (to the Legislative Assembly) to bring their number of seats to the guaranteed level of 308 [Dene Nation 1981:17]. However, non-Natives reavily protested the suggestion of a Denendeh Senate controlled by one cultural group, and the power of the proposed senate to make changes without input from non-Dene residents [cee G.N.W.T. 1982:9-13].

Although there has been no audible protest from the non-Natives of the Eastern Arctic over the prospect of having an Inuit majority in power, a consequence of a political system based on universalism ' 3 that "it can h:-ve negative consequences for minorities" [Asch and Dacks 1985:38]. There is the possibility that the nonNative minority in a future Nunavut territory might feel themselves to be in a position similar to the English Canadians in Quebec, where questions arise over the fairness of language and education policies. 
The Consociational model, realising that cultural communities can suffer under majority rule, attempts to meet the criteria of cultural equality with the veto mechanism equally accorded to each cultural group. First, it is assumed that the Founding charter:

"...will stipulate that each cultural community will have its own decision-making body or council to legislate on those basic constitutional matters which legislate on those matters which are set out in the charter or the basic constitutioral document of the new territory as fundamental to its cultural interest. Likely categories of powers include education, social policy, language and special programs of health care delivery" [Asch and Dacks 1985:44].

For example,

"...if a piece of leg-slation or any constitutional amendment is proposed which a majority of the M.L.A.s of any cultural community identifies as affecting its basic cultural rights as set out in the charter on the document which creates the institutions of government, then in order to be approved, the item in question must receive a majority of votes from the Assembly overall and from each of the cultural communities. In other words, the cultural veto which some have suggested be ensured by an aboriginal senate is obtained by creating assemblies within the assembly" "Asch and Dacks 1985:49].

\section{The Devolution of Power}

The devoiution of power is inextricably related to the future political development of the N.W.T.. As explained in chapter Two, devolution of power from the central authority tu the decolonizing territory has always been an important component of the Euro-Canadian 
definition of political development. However, EuroCanadian tradition and culture has produced a certain division of power between the Federal Government and the "developing" territory which is unacceptable to the Natives. This is mainly due to the fact that many of the decision-making powers that Natıves enjoyed within the local group, in traditional society, are under the jurisdictions of the Federal and Territorial Governments, in the Euro-Canadian system. Drury's observations help one to see that under the Euro-Canadian system of government, the local decision-making bodies in which the Natives are involved do not enjoy the decision-making power of the local groups in traditional Native society:

"The current jurisdictional areas of municipal councils relate primarily to the physical operation of hard services such as water, sewerage, garbage collection, road maintenance, zoning and community planning. The soft services, namely social and cultural matters, education, and land management, are largely excluded from the local process of decision-making. Many residents of the smaller communities regard the soft services as being critical to their lives, but ones over which they have little influence." [Drury 1980:36-35]

In discussing the goals of the Inuit, I.T.C. president, James Arvaluk, has said quite explicitly that Inuit seek, "a stronger voice in such fields as education, housing, health and welfare, social and political development and the running of our communities" [I.T.C. 1976:9]. The Nunavut Proposal called for the division of the N.W.T. and the most feasibly rapid devolution of powers to the 
Nunavut Territorial Government, including the eventual status of provincehood. In a subtle way, it proposes that certain powers now under the Federal Government's jurisdiction be accorded to the future Nunavut government, although a description of what these powers would be is not given [I.T.C. 1979:11]. After a brief discussion of Canadian federalism, it reminds one that:

"...constitutional practice provides for some flexibility with respect to jurisdiction, for example, the ability of Federal Government to delegate responsibility for the carrying out of some of its laws to provincial agencies. [I.T.C. 1979:11]"

The strategy appears to be that once powers are devolved to the Nunavut territorial (and eventually, provincial) government, the sooner the distribution of these powers can be reorganized within Nunavut, between the territorial (or provincial government) and the communities.

The Denendeh Proposal, like the Nunavut Proposal, calls for the devolution of powers and the attainment of provincial status. It also calls for the devolution of some federal powers to Denendeh which provinces were not given in the Constitution Act of 1867:

"We seek a relationship involving a clear division of powers, but this does not mean we wish to become a province in a traditional sense. Nevertheless, the similarities with a province may be greater than the differences.

Some of the powers traditionally fall within the jurisdiction of the provinces. Others are shared between the federal and provincial governments. A 
few of the powers are nov under the exclusive control of the Federal Government.

We advocate seeking new powers related to the protection and enhancement of aboriginal rights that are not within the jurisdiction of any present form of government. We believe they are necessary to express the uniqueness of northern people within Canada."

The settlement will provide that Denendeh become a "province-like" jurisdiction in Carada. By "province-like" we mean a political jurisdiction with powers similar to those of other provinces but not identical in that Denendeh may have some powers which other provinces do not have." [Dene Nation and Metis Association 1981:6; see also p.7]

\section{New Definition of Economic Development}

Much of the conflict and dissatisfaction in the N.W.T. respectinj economic "development" is due to the superimposition of the Euro-Canadian industrialized economy upon the Native economy. According to Berger, most non-Natives regaru hunting and trapping as neither "economically viable", nor "desireable", nor "relevant to the important pursults that distinguish the industrial way of life" [Berger 1977:88]. Berger further maintains that there has existed an attitude of "evolutionary determinism", among many non-Natives characterized as follows:

"The attitude of many white people toward the North and native northerners is a thinly veiled evolutionary determinism: there will be greater industrial development in which the fittest will survive; the native people should not protest, but should rather prepare themselves for the challenge that this development will present. It is inevitable that their viliages should cease to be native 
villages, for in this scheme, native villages are synonymous with regressive holdouts. 'Progress' will creute white towns, and the native people will have to become like whites if they are to survive. But this kind of determinism is a continuation of the worst features of northern history: southerners are once again insisting that a particular mode of 1 ife is the one and only way to social, economic and even moral well-being." [Berger 1977:89]

However, essential for the future political development of the N.W.T. is a more widely accepted definition of a viable economy. What is needed, and what many in the N.W.T. are working towards, is an economy based on the integration of the two different styles of economic development that have been at odds in the North. Non-renewable resource projects and the continuation of some form of traditional life based on renewable resources are not necessarily incompatible. Few of the Natives in the N.W.T. are philosophically opposed to industrial development. Duffy [1988:259] gives the example of the Inuit Development corporation's willingness "to take part directly in non-renewable resource development by becoming a partner in the cullaton Lake gold mine in Keewatin." However, the nene and Inuit oppose non-renewable resource projects which endanger the renewable resource base so essential to the maintenance of "their own independent livelihood and well-being" [Duffy 1988:259]. 


\section{Summary}

No proposal, presented thus far, is ideal. But they do contribute to the environment in which re-development can take place. In summary, the consociational model is successful at meeting the criteria of meaningful participation, cultural equality, and cultural protection, although it makes no plea for the devolution of any special powers to the present government or any future governments of the N.W.T.. There is also the objection that the Consociational Model is another European model and that it does not grow from the bottom up, but would be applied from the top down.

The Denendeh Proposal was an admirable attempt to create a basis for discussion concerning how the political system of a future western territory could be adapted to suit the political culture and aspirations of people in the western Arctic. Although the mechanisms (such as the Dene senate and 30 guaranteed representation) to achieve the objectives of the Natives may not have been acceptable to the non-Natives, the Denendeh Proposal helped non-Natives to realize the importance of cultural protection and meaningful participation. Unfortunately, attempts to meet these two criteria were at the expense of the equality of $: \because 1 \pm$ ural groups. The senate, for example, "creates the presumption that one community is threatening and the others are on 
the defensive" [Asch and Dacks 1985:49].

Lastly, the Euro-Canadian model, as has been pointed out, meet neither the criteria of meaningful participation, cultural protection, nor cultural equality for groups which are in the minority. However, it is the model upon which the Nunavut Proposal is based, although adaptions would be made, for example with the distribution of powers among the different levels of government. The Nunavut Proposal has great potential for allowing the meaningful participation and cultural protection of the Inuit because of the large number of Inuit that would be living within the boundaries of Nunavut. However, should the demographics of the Eastern Arctic ever change so that the Inuit became a minority group, they would risk losing a "real voice". If the demographics of the Eastern Arctic do not change significantly, there is will always be the risk that there will not be cultural equality between the Inuit and non-Natives, and cultural protection for the non-Inuit. 
Endnotes

1. Personal interview, in 1984, with Bill Erasmus who shortly thereafter became president of the Dene Nation. 
Chapter Five: Political Development and Political Culture

"Democracy, by its very nature, assumes a
participatory role for its citizens; yet in most
countries it remains an elusive goal never fully
attained, despite the rhetoric of constitutions and
politicians."

Robert Page

[ $1986: 25$ ]

Canada claims to be a democratic country. However, as will be pointed out, Canada has great trouble in achieving democracy. Nevertheless, the degree of difficulty is not found to be the same across the country. In this chapter, it will be argued that the Northwest Territories has both a unique political culture and a unigue political system which allow its inhabitants to approach democracy to the greatest degree possible in Canada. Futhermore, it will be argued that since democracy is an important aspect of Native political culture, the system of "consensus government" that exists in the Legislative Assembly of the Northwest Territories (N.W.T.L.A.) should be sustained and the push for party politics should be resisted since the practise of the latter would lessen the N.W.T.'s ability to achieve democracy.

Michael Whittington has noted that "sometimes even the most well-meaning attempts of white people to give the Natives the best of our political institutions-- 
institutions such as representative democracy -- have sometimes met with only marginal acceptance" [Whittington 1984:64]. It is true that many non-Native Canadians have been quite well-intentioned in their efforts to help the Native people in the North, especially in the area of political development. It is often felt by Euro-Canadians that they have offered the best that they have to the Native people, and yet "the best" has been politely ackowledged but not strongly accepted. There is a good reason why this occurs, especially with regard to the idea of introducing party politics to the N.W.T.L.A.. The reason revolves around the importance of democracy in N.W.T. political culture.

with regard to democracy, it has been charged that Canadians "no longer use the term... to refer to a situation in which masses of people participate, directly and meaningfully in the making of the directions which shape the basic conditions of their existence" [Horowitz 1970:241]. Rather, Canadians have apparently discovered that "this is an unattainable ideal -- which means not that it is absolutely, inevitably, and eternally unattainable, but that all our efforts to attain it have failed", says horowitz, and thus "Canadians have given up the ideal" and "now use the term 'democracy' to refer to the reality of our way of life" [Horowitz 1970:241]. Although opinions differ as to the nature of that 
reality, Horowitz states that the most common view may be :

"...that which was first formulated by Joseph Schumpeter, who defines democracy as 'rule of the politician' or, in a more extended phrase, as 'that institutional arrangement for arriving at political decisions in which individuals acquire the power to decide by means of a competitive struggle for the people's vote.' Those who hold this view believe that we have che second best thing to real democracy. The people do not have the power; their elected leaders have the power... the people act through their leaders". [Horowitz 1970:242]

However, some of Horowitz's earlier writings cast doubt as to whether this second best democracy (people acting through their ieaders) can be achieved in canada. The particular element of Toryism that is found in southern Canadian politicai culture influences canadian parliamentary government in a peculiar way. Horowitz [1966:21] has argued that adherents to Toryism believe in "loyalty, tradition and elitism" and that:

"...leaders should be given loyalty, deference, and support by the people, and should be permitted to govern as they think best, even at the risk of losing popularity. To the conservative, parliamentary democracy does not mean government by the people but rather 'government by ministers of the crown for the people.' Accordingly, conservatives hold that 'people should not presume to instruct their governors but [instead] trust them to govern well." [Horowitz 1966:2i]

Toryism has strongly influenced Canadian government. It has been argued that "parliamentary government is a result of Toryism... Toryism allows the Cabinet to be so powerful and unchecked" [Clarke et al 1980:309]. 
However, the system of government in the N.W.T. is very different from the other government systems existing at the federal and provincial levels in the rest of Canada, and in the Yukon Territory. One of the differences is that on the territorial level in the N.W.T. there is a lack of party politics. "The Legislative Asembly of the Northwest Territories is the only body in Canada which operates with a consensual type of decision-making" [Crombie 1984:1]. This means that there are no political parties 'which acquire the power to decide by means of a competitive struggle for the people's vote.' Rather, since party politics in the N.W.T.L.A. does not yet exist, Northerners have a unique chance to practise the closest approximation possible to the style of democracy that they most prefer and which Horowitz would consider to be first rate democracy.

The high degree of democracy practised in the N.W.T.L.A. at the present time is largely due to the influence of Native tradition and culture. For example, as Dacks points out:

"... Native people tend to see the people they elect to distant legislatures more as envoys than representatives. Thus, they do not want these politicians to make decisions on their behalf, but want them to return to them, to inform them of the issues at hand, and seek their instructions. Clearly this is a very different approach to legislating from the one most legislators bring to their jobs." [Dacks 1981:97]

Native people, in principle, are very active 
participants in their decision-making process. Dacks describes how: "Non-native politics... differs from Native politics, in that it proceeds through specialized structures of government involving a relatively small proportion of the population, while the rest contribute only intermittently to politics, usuaily electing people to represent them in the specialized forums of government" [Dacks 1981:97]. In contrast, there is heavy involvement by Natives in their own political process:

"The Native aproach tends to involve all adults actively in politics in several ways. Decisions are usually seen as properly made by the total group, not by some specialized organization. Thus, for example, Dene Nation assemblies attract large numbers of Dene people." [Dacks 1981:97]

The Native people of the N.W.T. have put a great emphasis on democracy in their proposals for future systems of government in the N.W.T.. For example, in the Denendeh proposal entitled "Public Government for People of the North" (a proposal written for the political system of a future territory in the Western Arctic), it is written that:

\footnotetext{
"Rather than representative government, we would encourage government by the people. Instruments through which the people could not only be consulted but really be a part of the decision on major policies would be the right of all people.

"The government of Denendeh will reduce the authority of elected officials and give more power to the people in running government." [Dene Nation and Metis Association 1981:6 J
}

The Inuit, as well, have expressed their desire for 
maximum Inuit participation in policy-making and in decision-making bodies in a future Nunavut government. In their proposal entitled "Building Nunavut" they have a number of principles to guide the establishment of a future Nunavut government. Two of these six principles deal with participation and decision-making. Inuit desire:

1. The maximum Inuit design and management of public services which affect them, including participation in programs and policy-making which significantly affect their regions;

2. Genuine political representation in provincial and territorial legislatures and the federal parliament, and in official bodies which make decisions affecting Inuit. [N.C.F. 1983:4]

When one looks at the Denendeh Proposal, one sees that at both the community level and the "provincial" level there would be an Assembly to assign tasks and give direction to its respective council/Executive. For example, the "community councils will be responsible for irplementing the tasks assigned by the community assemblies" [Dene Nation and Metis Association 1981:14]. In a similar manner to how the community assembly instructs its community council, the task of the "Provincial National Assembly" would be to "instruct the executive of Denendeh on the implementation of the policies and programs determined by the National Assembly" [Dene Nation and Metis Association 1981:17]. Even al the present time, there are communities in the 
N.W.T. exploring the use of community Assemblies. Instead of having decisions made by elected representatives, traditional forms of consensus decision-making may allow for wider community involvement. Flected leaders are still needed but they would be directly responsible through the Community Assembly.

For the Natives, "government by the people" has always been achieved through consensus decision-making which, when operating at its best, allows each individual to equally express his or her thoughts and opinions, and accords enough time for all to discuss an issue until a consensus has been reached by all (or nearly all) members and a decision is made by which all can live harmoniously, even the minority or dissenters, knowing that their viewpoint has been heard, respected, weighed and taken into account with the making of the final decision.

When the Dene derided to become involved en masse in the N.W.T.L.A. in 1979, they decided to bring their tradition of consensus decision-making with them. The goal in the N.W.T.L.A. since that year has been to pract_se "consensus government". However, there has been a certain disillisionment with the idea of "cons insus government" because of the difficulty in achieving consensus in the multi-ethnic environment of the N.W.T.. Along with complaints about the lack of consensus, there 
also arise complaints about the lack of leadership and lack of policy direction on the part of the government [Braden 1982:1].

Critics of the present system would give up "consensus government" in favor of parliamentary party politics. These critics maintain that specific policy and direction via a party platform would provide better government for the N.W.T.; party politics, it is argued, could satisfy the needs of the North for a leader and charted course of action [Braden 1982:2]. Also, instead of having 24 independent candidates running for office, each with a different platform from the others and each running on his or her record and reputation, political party candidates running for office would present the party platform to the electorate. Whichever party would form the government could chart a course for the four years during which they would be in power and follow that course. Thus, the critics argue, people would have a better understanding of what their M.I.A.s would do in the future if the M.L.A.s belonged to a party with a specific platform.

These are familiar arguments also made by those wishing to introduc- party politics at the municipal level of government; municipalities (local governmments) as well as the N.W.T.L.A. face pressure to adopt party politics for many of the same reasons. Nevertheless, as 
David siegel argued in an article refuting the necessity of party politics at the municipal level, "the standard arguments in favor of party politics...[sic] are not really as persuasive as some say" [Siegel 1987:26]. In response to the argument that "political parties provide real alternatives to guide citizens in their voting decisions" [Siegel 1987:26], Siegel writes the following:

"Anyone who makes this argument has not been following party politics in the federal and provincial spheres lately. It is true that federal anci provincial parties sometimes provide a unified approach to issues during an election campaign: occasionally, a winning party will even deliver on a few of its campaign promises, but most voters have learned not to count on that.

However, even when parties do provide a coherent policy structure they rarely provide real alternatives. In Canada, all serious parties agree on goals; the major issues in election campaigns can range from which party can deliver the agreed-upon goals better, to which candidate has the most winning smile.

one might lament this trivialization of the political process, but the purpose here is simply to point out the hope that... political parties will deliver consistent platforms and solid campaign fights based on those issues is not founded on what actually happens in election campaigns at other levels of government." [Siegel 1987:26]

He also refutes the argument that "...political parties will provide political leadership and policy initiatives..." [Siege] 1987:26]:

"... the implicit assumption that the present system does not produce leadership must be questioned.

The most serious problem with this reasoning, however, is that it. like the previous argument, overlooks lessons irom other levels of government. 
Prime Ministers and provincial premiers are frequently criticized for not providing leadership. Public servants in federal and provincial governments are frequently forced into positions of providing policy initiatives for their political masters, who may be too busy tending to internal party matters to become involved in governing. It is true that the party system could provide councillors [or M.L.A.S in the N.W.T.] with another source of policy initiatives, but most councillors [M.L.A.S] find that individual citizens are not shy about providing policy advice to them, even when they are not part of a party." [Siegel 1987:26]

Democracy is an important part of the political culture of the N.W.T.. We can see that it is something the people wish to maintain because of the importance placed on it in proposals for future systems of government. Why trade the closest approximation to first rate democracy for the second rate democracy to which the rest of Canada has become accustomed and which has been influenced by Toryism so that parliamentary democracy has become 'government by ministers of the crown for the people' rather than 'government by the people'? Perhaps parliamentary demoriacy with its party politics suits the political culture of sodthern Canada, but it does not suit northern politicai culture in the N.W.T..

In addition to the fact that party politics would not bring the advantages that its proponents suggest, party politics in a parliamentary system also greatly limits the ability of those governed to have input into the policy process. James Gilles explains that democratic government in a pluralistic society is founded upon the 
"consent doctrine" which is based on two assumptions: first, "that those governed do so with the consent of the governed"; and secondly, "that those who are governed have the right and responsibility to have an input into the formation of the laws under which they live" lGillies $1985: 14 \mathrm{~A}: 5]$.

Gillies goes on to comment that in Canada, the first of the two conditions is met (because any government which has lost the confidence of a majority of the elected representatives in the Legislatures must and does resign; in addition, the constitution requires that elections take place every five years and this gives the opportunity for Canadians to elect the government of their choice [Gillies 1985:14A:5]); however, the second condition is not being met and this condition is the root cause for the demands to reform the system. Gillies confirms the declining influence of the ordinary member of Parliament and explains the limit of thei nfluence:

"By the very nature of the policy-making process in the parliamentary system as it has evolved throughout the past century private members of parliament except in very specific circumstances have had little or no opportunity to be involved in the making of policy. They can and do, of course, argue for certain measures in their caucuses, they can and do speak on bills, and they can and do on occasion serve on special committees created to review some particular issue. But, by and large, the generalization that private members do not have substantial input into the formation of policy is correct and, because they do not in many respects, they are unable to sierve as an effective conduit for the views of their constitutents into the policymaking process. The reality is that 'the private 
member had been reduced to little more than a rubber stamp' and the 'system underutilizes... the talents and efforts of conscientious members....' All there is today in the words of one member 'is the minuet of committees [where]... government members fall neatly into file and toe the party line..." [Gillies 1985:14A:26-27]

Perhaps if some substantial gains were to be made, with the sacrifice of participatory democracy for parliamentary democracy, it would be worth the loss of ability to participate in decision-making. However, as siegel has astutely pointed out, the arguments in favor of adopting party politics are not all that persuasive.

In conclusion, it may be said that political party systems work relatively well in the federal and provincial governments. Ever in some southern Canadian cities, local political parties have grown because they have a role to fill in those cities. Nevertheless, just as it "would be dangerous to generalize from these facts to the idea that all local governments would benefit from the introduction of an eiectoral system which encourges the development of political parties" [siegel 1987:27], so it is equally dangerous to generalize from these facts to the idea that the N.W.T.L.A. would benefit from the introduction of political parties. Both local government and government of the N.W.T. are "different in many ways from the parliamentary forms found at the federal and provincial levels" [Siegel 1987:27]. Just as siegel has argued that it might be more beneficial to focus on and 
develop the factors which make local government unique "instead of importing structures into local government because they work well elsewhere" [Siegel 1985:27], so the same can be argued for the N.W.T.L.A. because of the unique political culture which exists there.

The present style of government in the N.W.T. does have a future and one should endorse the principle of consensus government for the sake of participatory democracy. A society which cherishes democracy should do its best to protect the unique chance that the N.W.T. has to practise next to ideal democracy. Unless there is a fundamental change in Native political culture, the introduction of parliamentary party politics would cause the Native people to become greatly alienated from the political system.

The fact is that the people in the North must settle for representative demociacy because of the structures of government that have been set in place in the N.W.T.; nevertheless, the principle of mass participatory democracy should be preserved by allowing the M.L.A.s the marimum influence possible over the policy-making process. Presently, M.L.A.s have a great freedom to influence policy, question and even counsel ministers and represent the wishes of theix constituency, instead of being obliged to represent the wishes of a party. The N.W.T. should do its best to avoid the following 
situation expressed by a Liberal backbencher from Toronto: "We're on call sometimes 14 or 16 hours a day just to support legislation that usuolly we didn't have any part in framing and sometimes don't even particularly like" [Van Loon and Whittington 1981:622].

If parliamentary party politics is forced in the N.W.T., the Natives will be stripped of a principle they have traditionally cherished and have struggled hard to maintain in modern times - that of individual participation in decision-making. Parliamentary party politics is not conducive to consensus decision-making in the Legislative Assembly. It is not even conducive to backbencher input, let alone participation by the masses.

\section{CONCLUSION}

The aim of this thesis has been to introduce a more appropriate framework with which to study the political development of the N.W.T.. In Chapter One, it has been shown that in Canada, there has existed two schools of thought regarding political development of the N.W.T.. Historically, political development has been seen as oneway: increasing, either slowly or quickly. The first school of thought considered political development to be ever increasing, as more of the Euro-canadian 
institutions of government have been adopted. If EuroCanadian institutions were being adopted quickly by the G.N.W.T. then political development was seen as picking up speed. If the G.N.W.T. was slow to adopt southern Canadian institutions, then the N.W.T. was judged to be developing more slowly, especially compared to the Yukon, for example, which would have adopted more EuroCanadian institutions by any same given time. The second school of thought argued that political change does not necessarily indicate political development. In the N.W.T., there has been much occuring in the way of political change; nevertheless, it has been questioned whether much of that change is indicative of political development.

It was felt that the political development-political decay framework created by Huntington, in the field of comparative politics, offered a better perspective from which to understand the poiitical history of the N.W.T..

Native societies have often been seen as politically underdeveloped. However, Huntington divorced his concept of political development from the concept of political modernization. This permitted the examination in chapter Two of traditional Native governmen $s$ as well-developed tribal societies with patzerns of governing welldeveloped to meet the demands made upon the system. Native society was, of course, less complex than Canadian 
government as we know it in the late 20 th century and, in comparison, demands made on traditional Native governments were relatively few. Nevertheless, Huntington's definition allows one to see that a less complex government can stil: be well-developed if it meets a high percentage of the demands placed upon it. This the Native governments did do very well, for thousands of years.

In Canadian literature there has been no concept of "de-development" or political decay. In Chapters Two to Four, Huntington's framework of political development and political decay was applied to the political history of the N.W.T.. Throughout these chapters, it was argued that the N.W.T. has oscillated between states of political development and political decay and that, at the present time, the N.W.T. is experiencing a period of political re-development.

As was seen in Chapter Two, there were many of Huntington's criteria for political development which were met by traditional Dene and Inuit goverments. organizations and procedures were strongly institutionalized because first, Native governments had a great chronological age. Secondly, Dene and Inuit goverments had great generational age. Leadership positions had been successfully handed down through thousands of generations. Thirdly, the traditional 
Native governments were stable and strengthened because of the diffuseness of the leadership. Native government did not depend on one leader in whom all power was concentrated and the death of whom would throw the society into disarray. Native government depended on many leaders and the diffuseness of the leadership gave the Native governments their stability. Fourthly, Native government was based on a philosophy of life that was coherent and unified. There was a strong consensus on appropriate behaviours and procelures. Lastly, Native organizations and procedures enjoyed a broad scope of support since they were accepted and followed by a large segment of the Native population.

Huntington's concept of political development and decay also helped it be seen that there were vulnerabilities in traditional Native governments in the area of autonomy and regulative capacity, vulnerabilities which, as seen in Chapter Three, weakened the level of institutionalization of Native government. Although weakened, the heavily institutionalized organizations and behaviors of Native society were by no means destroyed.

Understancing that there were many organizations and procedures from traditional Native government which continued to heavily institutionalized it was seen, in Chapter Three, how the superimposition of the EuroCanadian political system on the traditional forms of 
government led to the former's decay. The decay of the Euro-Canadian system, from World War II onwards was characterized by institutional decline and eventually by threats of domestic violence. Although the period of time between the end of the Second World and 1970 had been a time of great political change in the N.W.T., because of the adoption of many Euro-Canadian institutions it was not a time of corresponding political development since many of the criteria for political development, as set out by Huntington, were not met.

In Chapter Three it was seen that the Euro-Canadian political system had become neither heavily institutionalized nor had it succeeded in gaining a broad scope of support. First, it had not yet proven its adaptability and that it could survive challenges to its existence. It had neither attained a great chronological age nor could it claim a great generational age because the leadership of the Euro-Canadian political system had been governed for most of its existence by its first set of leaders, a small governmental elite, and by procedures still in use by those who first performed them. Although the Euro-Canadian system scored higher with respect to the criteria of complexity and autonomy, it lost ground on the more important criteria of coherency, as was seen by the fundamental disagreement which was occuring over economic priorities for the government. 
The Euro-Canadian system of government also did not enjoy a broad scope of support. Even when the Natives were finally allowed to vote and run for office, some of the them tried to participate in the Legislative Assembly but that system of decision-making was foreign to their culture and they had great difficulties with it. The frustration of the Natives grew, especially on the part of the Dene.

This political decay met its most severe moment of crisis around 1975. The particular dilemma for the EuroCanadian political system in 1975 was that, among the majority of residents of the N.W.T., it had become neither highly institutionalized nor did it enjoy c broad scope of support.

However, as seen in Chapter Four, there were several things which happened during the 1970 s which led to a significant diffusion of the frustration that was being felt. One particularly important move made on the part of the Federal Government was the appointment of Justice Berger to conduct an inquiry into the proposed building of the Mackenzie Valley Pipeline. Also, the Dene Nation mobilized to enter the N.W.T.L.A., en masse, in an attempt to bring about change. The election of a Native majority to the N.W.T.L.A., along with the electior of more open-minded non-Natives, led to a more agreeable and flexible policy, towards political development, on the 
part of the N.W.T.L.A.. Since the beginning of the 9 th Assembly, a concentrated effort has been encouraged by the N.W.T.L.A. to arrive at a new system and style of government which will be acceptable to N.W.T. residents, or which will, using Huntington's terminology, become highly institutionalized and enjoy a broad scope of support.

There have been various proposals made throughout the years. For example, the Nunavut proposal in 1976, the Denendeh Proposal in 1981, and the Consociational Model in 1985, have been put forward as suggestions for acheiving political development. Although a system and style of government would become heavily institutionalized has yet to be worked out, these proposals and the reactions to them have made clear a number of criteria which must be met for the future political development of the N.W.T.: meaningful participation, cultural protection, cultural equality, devolution of power, and a new meaning of what constitutes a viable econorny.

Chapter Five examined the question of whether introducing party politics to the N.W.T.L.A. would lead to political development. It was argued that because of the continuing imfortance of democracy in the political culture of the Native people, who make up a majority of the population, tree introduction of parliamentary party 
politics into the N.W.T.L.A. would not constitute politica: development, at the present time. Parliamentary party politics does not permit the broad and meaningful participation that Native people claim they wish to enjoy in the decision-making process.

This thesis is offered as a beginning step towards a new understanding of the political nistory of the N.W.T. and it claims, in no way, to be comprehensive in its study of the political development, political decay, and political re-development of the N.W.T.. For example, there is much room for further research on such topics as: additional factors leading to the political decay of both the Native and non-Native political systems; further criteria important to the re-development of the N.W.T.; the conflict which exists at the local level of government between the heavily institutionalized organizations and procedures remaining from traditional Nati.: government and the imposed system of municipal councils. As well, much work needs to be done in order to bring forth some comprehensive studies of traditonal Inuit government. It is hoped that this thesis might serve to motivate others to re-examine the political history of the N.W.T. so that new light and understanding may be shed on the meaning of past events. 


\section{B IBLIOGRAPHY}

Abele, Frances "Canadian Contradictions: Forty Years of Northern Political Development " ARCTIC Vol. 40, No.4, December 1987, pp.310-320.

Abele, Frances "Conservative Northern Development Policy: A New Broom in an Old Bottleneck?" How Ottawa Spends edited by Michael J. Prince Ottawa: Carleton University Press, 1987.

Abele, Frances and Dickerson Mark o. "The 1982 Plebiscite on Division of the Northwest Territories: Regional Government and Federal Policy Canadian public Policy XI no. 1 March 1985 ppl-15.

Aboriginal Rights and Constitutional Development secretariat "Our Land, Our Future" Yellowknife, 19 October 1981.

"Working paper for tae second western Arctic Constitutional confererce september 14-16, 1982" Yellowknife: 1 september 1982 .

"Creating a Better Tomorrow: Aboriginal Claims in the Northwest Territories" Yellowknife, N.W.T., 1986.

Almond, Gabriel A. et al Crisis, Choice and Change: Historjcal studies of Political Development Boston: Little, Brown and Company 1973.

Almond, Gabriel A. and Verba, Sidney The civic culture Boston: Little, Brown and Company Inc. 1965.

Arima, Eugene Y. "Caribou Eskimo" Handbook of North American Indians Volume 5: Arctic washington: Smithsonian Institution, 1984 . pp.447-462.

Armstrong, T. Rogers G., and Rowley G., The Circumpolar North Toronto: Methuen \& Co. Ltd., 1978 .

Asch, Michael "The Dene Economy" in Dene Nation:the colony within (edited by Mel Watkins) Toronto: University of Toronto Press, 1977. Pp 49-61.

Asch, Michael "Slavey" Handbook of North American Indians Volume 6: Subarctic washington: Smithsonian Institution, 1981. pp.338-349.

Ascl, Michael and Dacks, Gurston "The Relevance of consociation to the "Western Northwest Territories" Partners for the Future Yellowknife, N.W.T.: Western Constitutional Forum, 1985. 
Baldwin, Susan "A Procedural Clerk Goes North" Canadian Parliamentary Review Autumn 1983, pp.23-29.

Balikci, Asen "Netsilik" Handbook of North American Indians Volume 5: Arctic Washington: Smithsonian Institution, 1981 . PD 338-349.

Berger, Thomas Northern Frontier, Northern Homeland: The Report of the Mackenzie valley Pipeline Inguiry-Volume one Ottawa: Supply and Services Canada, 1977.

Bill, James A. and Hardgrave, Comparative Politics: $T$ h e Quest for Theory ohio: Charles E. Merrill Publishing Company, 1973 .

Binder, Leonard et al. Crisis and Sequences in Political Development Princeton, New Jersey: Princeton University Press, 1971 .

Birket-Smith, Kaj "The Caribou Eskimos" The Fifth Thule Expedition Volume V New York, AMS Press, 1976.

translated from Danish Reprint of the 1929 edition published by Gyldendal, Copenhagen, which was issued as Volume $V$ of the Fifth Thule Expedition 1921-24.

Bovey, John "The Growth of N.W.T. Government" NORTH Vol.13, No. 4,1966 .

Braden, George "Party Politics: Let's Be Leaders -- A Draft" unpublished, 1982 .

Brockman, Aggie and Iveson, Steve Western Constitutional Forum: Chronology of Events, January 1982-June 1987 Yellowknife: Western Constitutional Forum, 1987.

Clark, Donald W. "Prehistory of the western Subarctic" Handbook of North American Indians Volume 6: Subarctic Washington: Smithsonian Institution, 1981.

Clarke, Harold et al. Parliament, Policy and Representation Toronto: Meuthen Publications, 1980 .

Crombie, David (personal letter to the author), 1984 .

Dacks, Gurston A Choice of Futures: Politics in the Canadian North Toronto: Methuen Publications, 1981 .

Dacks, Gurston "Politics on the last Frontier: Consociationalism in the Northwest Territories" Canadian Journal of Poljtical Science XlX:2 (June 1986).

Damas, David "Central Eskimo: Introduction" and "Copper 
Eskimo" in Handbook of North American Indians Volume 5: Arctic Washington: Smithsonian Institution, 1984 . pp. 391-414.

Dene Nation DENENDEH: A Dene Celebration Yellowknife, N.W.T.: The Dene Nation, 1984 .

Dene Nation and Metis Association "Public Government for People of the North" Yellowknife: The Dene Nation and the Metis Association, 9 November 1981.

Dickerson, Marc 0 . "Commentary: The Drury Report and PoliticalDevelopment in the N.W.T." ARCTIC Vol. 35, No. 4, December 1982 .

Dosman, Edgar "The Mackenzie Valley Pipeline Inquiry: The Politics of Catharsis" Canadian Ethnic Studies Vol. 10, no.1, i978, pp.135-141.

Drury, C.M. Constitutional Development in the Northwest Territories -- Report of Special Representative Ottawa: Supply and Services Canada, 1979.

Duffy, R. Quinn The Road to Nunavut Kingston and Montreal: MCGill-Queen's University Press, 1988.

Fumoleau, Rene As Long As This Land Shall Last Toronto: McClellend and Stewart Limited (no date)

Gillespie, Beryl C. "Mountain Indians"(pp.326-337), "Yellowknife Indians(pp.285-290), "Bearlake Indians"(pp.310-313), "Territorial Groups before 1821: Athapaskans of the Shield and the Mackenzie Drainage"(pp.161-168), and "Nahanni"(pp.451-453) in Handbook of North American Indians volume 6: Subarctic washington: Smithsonian Institution, 1981.

Giilies, James "The Role of Committees of Parliament in Policy Formation" House of Commons Committee on Reform of the House of Commons No. 1-14 33rd. Parliament 1st session, 1984-85 (see appendix, pp 14A:1-13).

Government of the Northwest Territories The Council of the Northwest Territories (no date) Northwest Territories Legislative Assembly 1979/80

"Working Paper for the Second Western Arctic Constitutional Conference" September 14-16, 1982 .

Ninth Legislative Assembly of the Northwest Territories Yellowknife: Northwest Territories Information, 1983.

Hearne, Samuel P. "A Journey from Prince of wales Fort in Hudson's Bay to the Nrythern Ocean in the Years 1769, 
1770, 1771, and 1772 [1795]" R. Glover, ed. New ed. Toronto: Macmillan, 1958.

Helm, June "Leadership Among the Northeastern Athabascan" Anthropolica 1956, pp.131-164.

Helm, June "Dogrib"(pp.291-311) and "Native settlements: Introduction" (pp.664-665) in Handbook of North American Indians Volume 6: Subarctic washington: Smithsonian Institution, 1981 .

Honigmann, John "Expressive Aspects of Subarctic Indian culture" in Handbook of North American Indians: Subarctic Volume 6 Washington: Smithsonian Institution, 1981. pp.718-738.

Honigmann, John "Frobisher Bay Eskimo Leadership" in North Volume XII, number 3: May-June, 1965, pp. 38-47.

Horowitz, Gad "Towards the Democratic Class : iruggle" Agenda $\underline{1970}$

Huntington, Samuel P. "Political Development and Political Decay" World Politics 17 (1965).

Huntington, Samuel $P$. "The Change of Change: Modernization, Development and Politics" Comparative Politics 3 (A.pril 1971 ).

Inuit Tapirisat of Canada "Agreement in Principle as to the settlement of Inuit Land claims in the Northwest Territories and the yukon Territory between the Government of Canada and the Inuit Tapirisat of Canada", 27 February 1976.

"Political Development in Nunavut", 1979.

Ju11, Peter "Next steps for Nunavut" Policy Options Vol.3, no. 5 September/October 1982 . pp.6-10

Jull, Peter Politics, Development and Conservation in the International North Ottawa: Canadian Arctic Resources Committee, 1986.

Kakfwi, steve "Letter to Chiefs and Subchiefs" in western Constitutional Forum: Choronology of Events, January 1982 June 1987 Yellowknife: Western Constitutional Forum, 1987 .

Kemp, william B. "Baffinland Eskimo" in Handbook of North American Indians: Arctic Volume 5 washington: Smithsonian Institution, 1984. Pp.463-475. 
Malloch, Lesley Dene Government: Past and Future

Yellowknife: The Dene Nation, 1984.

Mary-Rousseliere, Guy "Iglulik" in Handbook of North American Indians: Arctic volume 5 washington: Smithsonian Institution. pp. 431-446.

Noble, william c. "Prehistory of the Great slave Lake and Great Bear Lake Region" Handbook of North American Indians: Subarctic, Volume 6 Washington: Smithsonian. Institution, 1981 .

Nunavut Constitutional Forum NUNAVUT Yellowknife: Northwest Territories Information, 1983.

Nunavut Constitutional Forum Building Nunavut, 1983.

Overvold, Bob "Address to the N.W.T. Legislative Assembly" Legislative Assembly of the Northwest Territories Debates 2nd session, 9 th Assembly, Yellowknife, Tuesday March 11, 1980, pp. 1335-1346.

Page, Robert Northern Development: The Canadian Dilemma Toronto: McClelland And Stewart Limited, 1986.

Parker, Catherine "The Political Evolution of the N.W.T. and Yukon: A Perpetuation of Colonialism" (unpublished paper), July 1988 .

Pye, Lucien $w$. and Verba, sydney political culture and Political Development Princeton, New Jersey: Princeton University Press, 1955.

Savishinsky, Joel $S$. and Hiroko, Sue Hara "Hare" in Handbook of North American Indians: Subarctic Volume 6 washington: Smithsonian Institution, 1981. pp 314-325.

Siegel, David "City Hall Doesn't Need Parties" Policy Options June 1987, pp.26-27

Slobodin, Richard "Kutchin" in Handbook of North American Indians: Subarctic volume 6 washington: Smithsrian Institution, 1984. Pp.514-532.

Smith, David M. "Fort Resolution Northwest Territories" in Handbook of North American Indians: Subarctic Volume 6 Washington: Smithsonian Institution, 1981. pp. 683-693.

Smith, James G. E. "Chipewyan" in Handbook of North American Indians: Subarctic volume 6 wasilington: Smithsonian Institution, 1981. Pp. 271-284. 
Steenhoven, Geert van den Leadership and Law Anong the Eskimos of the Keewatin District, 1959.

Swalm, J.H. "Baffin Island Inuit: Consensus or Anarchy" unpublished paper, 1984.

Thomas, L.H. The Struggle for Responsible Government 1870-9? 2nd. edition. Toronto: University of Toronto press, 1956 .

Watkins, Mel Dene Nation: the colony within Toronto: University of Toronto Press, 1977.

Whittington, Michael "Canada's North in the Eighties" Canadian Politics in the 1980s Toronto: Metheun Publications, i981, and 2nd edition, 1984 .

Whittington, Michael The North Toronto: University of Toronto Press, 1985.

Western Constitutional Forum

1. Our Colonial Past

2. Why This Approach?

3. What Are the Issues?

4. What is Northern Society?

5. Aboriginal Rights

6. Guaranteed Representation

7. Toward Provincial Status

8. Balancing Power in the North

9. Denendeh: A Proposal

10. Division: Past Examples

11. Division: What's Achieved?

12. Choosing a Boundary

Yellowknife: Canarctic Graphics Ltd., 1984.

Zaslow, Morris The Northwest Territories 1905-1980 Historical Booklet no.38 ottawa: The Canadian Historical Society, 1984. 

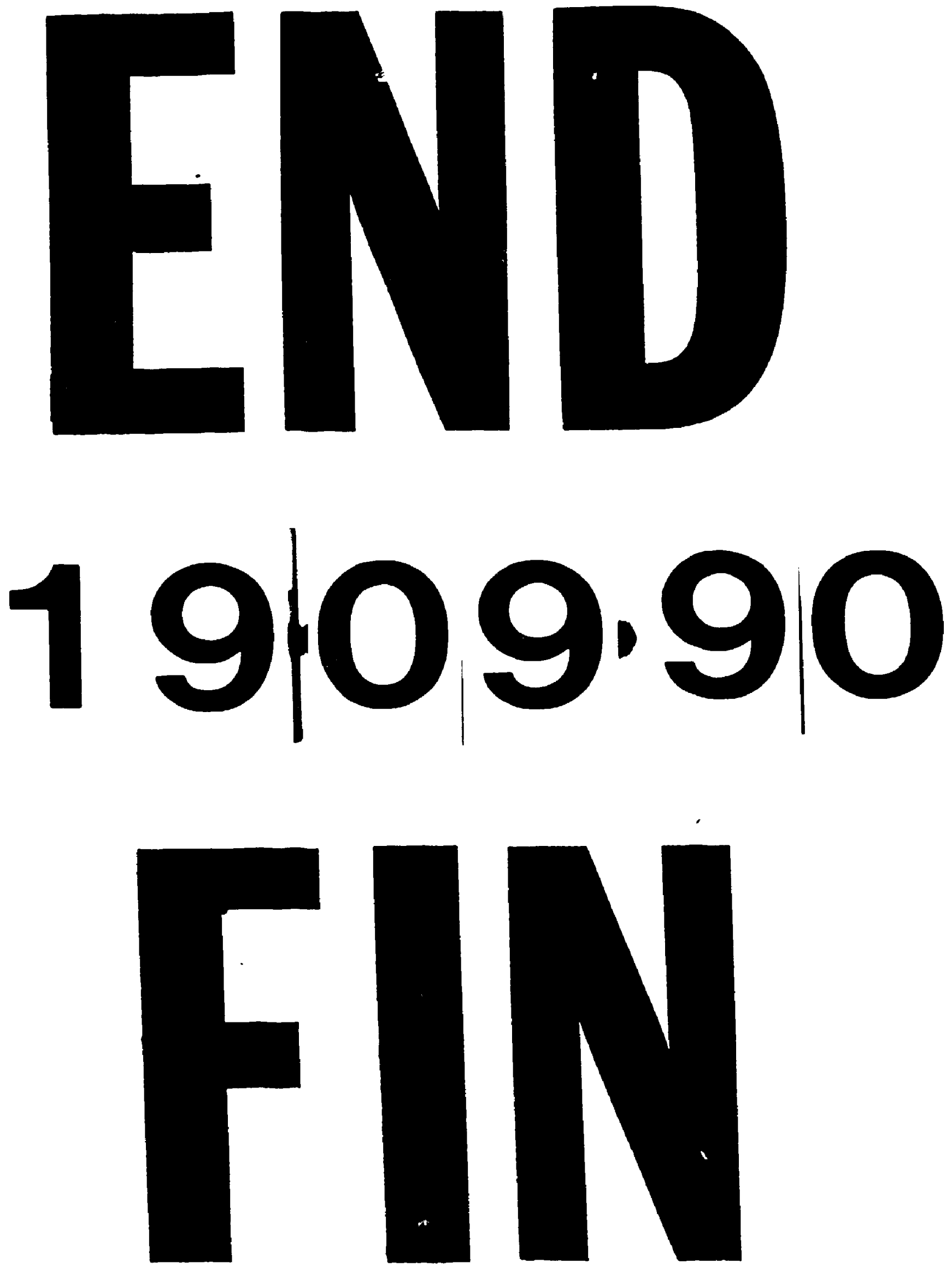